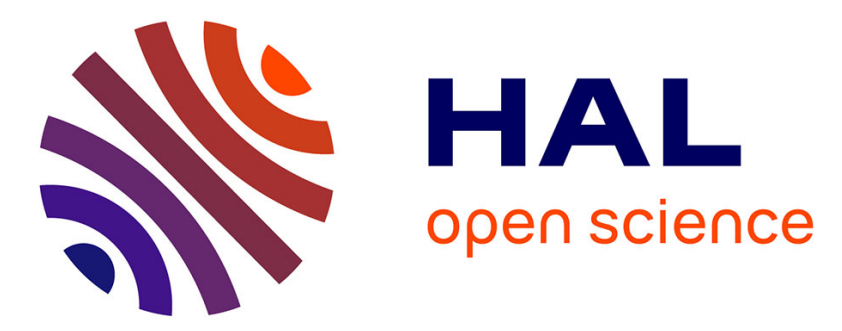

\title{
Expression and modulation of neuroligin and neurexin in the olfactory organ of the cotton leaf worm Spodoptera littoralis
}

Nicolas Durand, Thomas Chertemps, Francoise Bozzolan, Martine Maïbèche

\section{- To cite this version:}

Nicolas Durand, Thomas Chertemps, Francoise Bozzolan, Martine Maïbèche. Expression and modulation of neuroligin and neurexin in the olfactory organ of the cotton leaf worm Spodoptera littoralis. Insect Science, 2016, 24 (2), pp.210-221. 10.1111/1744-7917.12312 . hal-01306772

\section{HAL Id: hal-01306772 \\ https://hal.sorbonne-universite.fr/hal-01306772}

Submitted on 25 Apr 2016

HAL is a multi-disciplinary open access archive for the deposit and dissemination of scientific research documents, whether they are published or not. The documents may come from teaching and research institutions in France or abroad, or from public or private research centers.
L'archive ouverte pluridisciplinaire HAL, est destinée au dépôt et à la diffusion de documents scientifiques de niveau recherche, publiés ou non, émanant des établissements d'enseignement et de recherche français ou étrangers, des laboratoires publics ou privés. 


\section{Expression and modulation of neuroligin and neurexin in the olfactory organ of the cotton leaf worm Spodoptera littoralis}

Durand N., Chertemps T., Bozzolan F. and Maïbèche $M^{*}$.

Sorbonne Universités UPMC - Univ Paris 06, Institut d'Ecologie et des Sciences de l'Environnement de Paris, INRA, CNRS, IRD, UPEC, Département d'Ecologie Sensorielle, F75252, Paris, France

* Correspondence: Dr Martine Maïbèche. Institut d'Ecologie et des Sciences de l'Environnement de Paris, Département d'Ecologie Sensorielle, 7 Quai St-Bernard, BC 1211, F-75005 Paris, France.

Tel: + 33 144276592; Fax: + 33 144276509; e-mail: martine.maibeche@upmc.fr

Running tittle: antennal Carboxylesterase-Like Adhesion Molecules 


\section{Abstract}

Carboxylesterases are enzymes widely distributed within living organisms. In insects, they have been mainly involved in dietary metabolism and detoxification function. Interestingly, several members of this family called Carboxylesterase-Like Adhesion Molecules (CLAMs) have lost their catalytic properties and are mainly involved in neuro/developmental functions. CLAMs include gliotactins, neurotactins, glutactins, neuroligins. The latter have for binding partner the neurexin. In insects, the function of these proteins has been mainly studied in Drosophila central nervous system or neuromuscular junction. Some studies suggested a role of neuroligins and neurexin in sensory processing but CLAM expression within sensory systems has not been investigated. Here, we reported the identification of five putative CLAMs expressed in the olfactory system of the model pest insect Spodoptera littoralis. One neuroligin, Slnlg4-yll and its putative binding partner neurexin $\operatorname{Sln} r x I$ were the most expressed in the antennae and were surprisingly associated with olfactory sensilla. In addition, both transcripts were upregulated in male antennae after mating, known to modulate the sensitivity of the peripheral olfactory system in S. littoralis, suggesting that these molecules could be involved in sensory plasticity.

Keywords : neuroligins, neurexin, Carboxylesterase-Like Adhesion Molecules ; olfaction ; insect

Abbreviations : CLAM: Carboxylesterase-Like Adhesion Molecules; CCE: carboxylesterases; NLG: neuroligins; NRX: neurexin 


\section{Introduction}

Carboxylesterases or CCEs (EC 3.1.1.1) belong to a multigene family of enzymes widely distributed in animals, plants and microorganisms. They are involved in various functions, from xenobiotic detoxification to development regulation and neurogenesis. In insects, CCEs are known to play a key role in insecticide resistance and detoxication of plant allelochemicals. Some CCEs have been involved in specific functions, such as acetylcholinesterase (AChE) or juvenilehormone esterase (JHE) (reviewed in (Oakeshott et al. 2005)). Several others are proposed to have a function in olfaction as odorant-degrading esterases (reviewed in (Leal 2013)). However, the physiological role of most insect CCEs is unknown. Based on substrate specificity and sequence similarity, insect CCEs have been divided into eight subfamilies: four of them, the $\alpha$ esterases, $\beta$-esterases, AChEs and JHEs account for the majority of the enzymatic active CCEs that use a catalytic mechanism based on a triad featuring a serine nucleophile residue (Oakeshott et al. 2005). Four other subfamilies, namely neuroligins, gliotactins, neurotactins and glutactins are considered to be non-catalytic proteins. These CCEs have lost one or more of the active site residues, but have gained new structural characteristics such as transmembrane and binding domains and are also called Carboxylesterase-Like Adhesion Molecules (CLAMs). They are mainly associated with the promotion of cell adhesion during neural development (reviewed in (Gilbert and Auld 2005; Johnson and Moore 2013)).

In insects, functional data on gliotactin (Auld et al. 1995), neurotactin (Barthalay et al. 1990) and glutactin (Olson et al. 1990) are only available for Drosophila melanogaster (review in (Oakeshott et al. 2005)). The transmembrane protein Gliotactin is involved in the formation of septate junction in epithelia (Schulte et al. 2003) and in the establishment and maintenance of the blood-nerve barrier in peripheral glia (Auld et al. 1995). Neurotactin is also a transmembrane 
glycoprotein (Barthalay et al. 1990). It binds to the secreted protein Amalgam and the resulting complex is responsible for axon guidance in Drosophila embryo (Frémion et al. 2000). Glutactins are secreted proteins forming part of the basement membrane. They are abundant in the envelope of the central nervous system (CNS) (Olson et al. 1990), but precise information on their function is lacking.

Contrary to the other CLAMs, neuroligins (NLGs) and their principal binding partner neurexin (NRX) are present in all animal phyla. They have been mainly studied in mammals and implicated in various neuronal processes, including the differentiation, maturation, stabilization and plasticity of synapses. Mutations in NLGs and NRXs in humans have been linked to several cognitive diseases, in particular autism (review in (Bang and Owczarek 2013)). If most of the NLGs and NRXs from mammals were brain-specific proteins, some of them also exhibited a more ubiquitous expression pattern, such as in the vascular system, suggesting other functions in the peripheral tissues (review in (Bang and Owczarek 2013; Bottos et al. 2011)).

In insects, NLGs and NRXs have been characterized in the fruit fly and in a lesser extend in the honey bee Apis mellifera. NRXs and NLGs are known as trans-synaptic binding partners and are mostly expressed in the presynaptic and post-synaptic compartments, respectively (Knight et al. 2011). D. melanogaster possesses four $n l g$ genes expressed at synapses from the CNS and/or the neuromuscular junctions (NMJs): dmnlg1 (Banovic et al. 2010; Mozer and Sandstrom 2012) and dmnlg2 (Chen et al. 2012; Sun et al. 2011) are required independently for synaptic growth and function. dmnlg3 played a role in the NMJ development and synaptic maturation (Xing et al. 2014), whereas dmnlg4 is expressed in clock neurons and is essential for sleep regulation (Li et al. 2013). Five NLGs were found in the bee, all of them are mostly expressed in the brain, except Amnlg1 which is more abundant in peripheral tissues (Biswas et al. 2008). Two NRXs were identified in Drosophila: $n r x I V$ is distantly homologous to vertebrate neurexins and is mainly 
expressed in the septate junctions of glial and epithelial cells (Baumgartner et al. 1996) but also in the midline neurons (reviewed in (Sun and Xie 2012)). NrxI is highly expressed in the brain, including the adult antennal lobes and mushroom bodies (Li et al. 2007; Zeng et al. 2007), two structures involved in olfactory learning and integration of sensory information. Moreover, NrxI has been also involved in sleep regulation (Larkin et al. 2015).

Several studies suggested a link between NRX-NLG function and sensory processing in insects (reviewed in (Knight et al. 2011)). In Drosophila, DmnrxI is required for synapse formation and associative learning in larvae (Zeng et al. 2007). In the honeybee, sensory deprivation resulted in Amnlgl reduced expression, while associative scent training induced an increasing of AmnrxI and Amnlgn3 expression (Biswas et al. 2010). AmnrxI and Amnlg3 genes were mostly expressed in the mushroom body of the adult brain, a pattern consistent with a role in sensory signalling and cognitive processing. Several Amnlg/nrx genes were in addition expressed outside the brain, putatively in the peripheral nervous system but their expression in the bee olfactory system has not been studied.

Identification of CLAMs within antennae has been done previously only in two species, $D$. melanogaster (Younus et al. 2014) and the blowfly Calliphora stygia (Leitch et al. 2015), through transcriptomic analysis, but without any detailed study of their expression patterns within this sensory tissue. The pest moth Spodoptera littoralis is a main model to study olfactory reception and its plasticity in insects. While the modulation of the peripheral olfactory system by circadian rhythms, physiological state, experience or mating has been well studied in this species (Bigot et al. 2011; Guerrieri et al. 2012; Martel et al. 2009; Merlin et al. 2007), the underlying mechanisms are still unknown. Using an EST library approach, we previously revealed an unsuspected diversity of 30 CCEs expressed in the antennae of this species (Durand et al. 2010b), including one glutactin-like (Durand et al. 2012). Among them, we functionally characterized 
two active CCEs as odorant-degrading esterases (Durand et al. 2011; Durand et al. 2010a). We have now completed this repertoire with five new antennal CCEs belonging to the CLAMs. We identified single homologue of gliotactin and neurotactin, three homologues of neuroligin and one of neurexin I. We compared their expression profile in different adult tissues and, for the two genes abundantly expressed in the olfactory organ, i.e Slnlg4-yll and SlnrxI, we investigated whether their expression could vary in the antennae depending on the male mating status, known to trigger plasticity of the peripheral olfactory system. The involvement of NLG/NRX in synaptic plasticity makes them putative candidates for such a modulation. 


\section{Material and methods}

Insects and tissue collection

Insects were reared on semi-artificial diet at $24^{\circ} \mathrm{C}, 60-70 \%$ relative humidity, and under a 16:8h light:dark (LD) photoperiod until emergence. Sexes were separated at pupal stage. Adults were kept under an inverted LD regime and provided with a $10 \%$ sucrose solution. Antennae and various tissues (proboscis, brain, leg, thorax and abdomen) from two day-old adults were dissected and stored at $-80^{\circ} \mathrm{C}$ until RNA or protein extraction. For mating experiments, 15 oneday old insects of each sex were kept together for 24 hours into hermetically sealed boxes. Under these conditions, males started mating within a few minutes. Subsequently, male antennae and brains were then dissected 24 hours after mating. Control males were kept in the same conditions but without females.

\section{RNA isolation and cDNA synthesis}

Total RNAs were extracted with TRIzol Reagent (Invitrogen, Carlsbad, CA, USA) then treated with DNase I (Roche, Basel, Switzerland) in accordance with the manufacturers' protocols and quantified with a spectrophotometer (BioPhotometer, Eppendorf, Hamburg, Germany). Single-stranded cDNAs were synthesized from total RNAs $(5 \mu \mathrm{g})$ from various tissues with Superscript II reverse transcriptase (Gibco BRL, Invitrogen) with the oligo(dT)18 primer according to the manufacturer's instructions. For 5' and 3'-RACE PCR, antennal cDNAs were synthesized from $1 \mu \mathrm{g}$ male antennal RNA at $42^{\circ} \mathrm{C}$ for $1.5 \mathrm{~h}$ using the SMART RACE cDNA Amplification Kit (Clontech, Mountain View, CA, USA) with 200 U of Superscript II, 3'-cDNA synthesis-primer and SMART II oligonucleotide. 


\section{Identification and cloning of Spodoptera littoralis CLAM sequences}

Putative CLAM sequences were identified from $S$. littoralis antennal EST libraries (Jacquin-Joly et al. 2012; Legeai et al. 2011) by local TBLASTN analysis with the BioEdit Sequence Alignment Editor software (http://www.mbio.ncsu.edu/bioedit/bioedit.html) and using CLAM sequences from B. mori as queries. These libraries represented a total of 13,685 unigenes corresponding to $11,000-12,000$ expressed genes, thus covering the majority of the transcripts in this species. ESTs were assembled and the missing regions of the corresponding transcripts were obtained by PCR or RACE-PCR using primers designed with AmplifX software v. 1.5.4 (Montpellier, France) in conserved regions of each gene (Table S1). The complete ORF were amplified from antennal cDNA with a high fidelity Taq DNA polymerase and sequenced. For missing 5' or 3' regions, 5'- and/or 3'-RACE-PCR (SMART RACE cDNA Amplification Kit, Clontech) were performed. For 5'-RACE, we used $2.5 \mu 1$ of 5'-RACE-ready cDNA with specific reverse primers and Universal Primer Mix (UPM, Clontech) as anchor primer. 3'-RACE amplifications were carried out with UPM as reverse primer and specific forward primers. PCR were performed using hot start as follows: after $5 \mathrm{~min}$ at $94{ }^{\circ} \mathrm{C}, 35$ cycles of $30 \mathrm{~s}$ at $94{ }^{\circ} \mathrm{C}, 30 \mathrm{~s}$ at $55^{\circ}$ and $3 \mathrm{~min}$ at $72{ }^{\circ} \mathrm{C}$, then $10 \mathrm{~min}$ at $72{ }^{\circ} \mathrm{C}$. The PCR products were purified (Nucleospin Extract II, Macherey-Nagel, Düren, Germany) and cloned into pCRII-TOPO plasmid (Invitrogen). After isolation (Nucleospin Plasmid, Macherey-Nagel), recombinant plasmids were sequenced (GATC Biotech, Marseille, France) and the overlapping sequences manually assembled to obtain full-length cDNAs. PDZ motifs were identified using the POW software (http://webservice.baderlab. org/domains/POW/). 
Phylogenetic analysis

A dataset of 47 insect CLAM sequences was created, including sequences from $D$. melanogaster, A. mellifera, T. castaneum and B. mori and seven sequences from S. littoralis. Alignment was performed with CLUSTALW and used to create an entry file for phylogenetic analysis. An unrooted tree was calculated by the neighbor-joining method with Poisson correction of distances using the MEGA 6 program (Kumar et al. 2004) with default settings. Branch support was assessed by a bootstrap analysis based on 1000 replicates. Gene names were chosen according to previous CCE phylogenetic studies (Oakeshott et al. 2010; Teese et al. 2010; Tsubota and Shiotsuki 2010).

Expression analysis by RT-PCR and quantitative RT-PCR ( $q P C R)$

Tissue distribution of $S$. littoralis CLAMs was first investigated by RT-PCR. Equal amounts of RNA (5 $5 \mathrm{~g}$ ) extracted from male tissues and female antennae were reversetranscribed. Primer pairs are indicated in Table S1. The ubiquitous ribosomal Slrpl13 gene, which presents a constant expression in all tissues tested, was used to check the quality of the cDNAs. PCR products were loaded on 1\% agarose gels and visualized using Gel Red (VWR, Radnor, PE, USA).

Amplification by qPCR of Slnlg4-yll, SlnrxI, Slnrt, Slgli and the reference gene Slrpl13 was performed as described in detail in (Durand et al. 2010a) using the LightCycler $480^{\circledR}$ Real-Time PCR System (Roche). Each reaction was run in triplicate with at least three independent biological replicates. Data were analysed with LightCycler $480^{\circledR}$ Software (Roche). The crossing point values (Cp-values) were first determined for the reference genes with a run formed by the fivefold dilution series, the measuring points and three negative controls. The normalized expressions were thus calculated with Q-Gene software (Simon 2003) using SlrpL13 as reference. 
This gene has been already demonstrated as the best reference gene in these conditions (Durand et al. 2010a). Statistical analyses were performed with STATISTICA 7 (StatSoft Inc., Tulsa, OK, USA). A Mann-Whitney $U$-test was used for pair-wise comparisons.

In situ hybridization

For $\operatorname{sinlg} 4-y l l$ and $\sin r x I$, cDNA fragments of respectively 748 bp and 565 bp were amplified by PCR using specific primers (Table S1), purified (Nucleospin Extract II, Macherey-Nagel) and cloned into pCRII-TOPO plasmid (Invitrogen), used as template for in vitro transcription to generate DIG-labeled RNA sense and antisense probes. The Pheromone-Binding protein SIPBP1 (GenBank accession number EF396284), whose transcripts are highly expressed in male antennae, was used as positive control. Antennae from three-day-old male moths were embedded in Tissue Tek 186 medium $^{\mathrm{TM}}$ compound (CellPath, Newtown Powys, UK). Cryosections $(7 \mu \mathrm{m})$ were set in cell culture insert (Greiner Bio-one, Monroe, USA). Hybridization was conducted as described previously (Durand et al. 2010a). Pictures were acquired (Olympus BX61 microscope, ImagePro software) and digitalized using Adobe Photoshop ${ }^{\circledR} 7.0$ (Adobe, USA). 


\section{Results}

Sequence and phylogenetic analyses

The partial deduced gliotactin sequence (Slgli; Genbank accession number KP308209) consisted in $891 \mathrm{bp}$ and contains a signal peptide and a part of the CCE domain, including a "HGG" version of the oxyanion hole. Despite several attempts using different primers and PCR conditions, we were unable to clone the 3' part of this gene, thus the expected transmembrane and intracellular domains, as deduced from alignment with its B. mori orthologue, were lacking.

The complete neurotactin (Slnrt, KP308208) consisted of 2238 bp. The deduced protein contained a predicted N-terminal extracellular domain, a transmembrane domain (amino-acids 221-243) and a C-terminal intracellular domain. The catalytic serine is replaced by an arginine residue. Unlike Drosophila neurotactin, but as its B. mori orthologue, SINRT deduced protein did not contain the triad's glutamate and histidine residues, nor the three LRE (Leu-Arg-Glu) adhesion motifs involved in protein-protein interactions.

Three sequences of putative $n l g$ genes were named according to their presumptive orthologs in other insect neuroligins, especially B. mori: neuroligin 1 (Slnlg1, KP308205), neuroligin 4 y-linked-like (Slnlg4-yll, KP308206) and neuroligin 5 (Slnlg5, KP308207). The three $n l g$ sequences exhibited the predicted extracellular, transmembrane and cytosolic domains found in insect neuroligins. Slnlg4-yll and $\operatorname{Sln} \lg 5$ were full-length cDNAs with coding sequences containing respectively 3,129 and 2,307 bp (Fig. S1 and S2). They both retained putative Cterminal PDZ motif involved in protein-protein interactions and possessed a putative signal peptide at their N-terminus. $\operatorname{Sln} \lg 1$ partial sequence contained 4,132 bp and alignment with its $B$. mori homologue (Tsubota and Shiotsuki 2010) revealed that the sequence lacks both the signal peptide and the first part of the CCE domain. As for Slgli, we were unable to verify the 5' part of 
this gene. Slnlg1 partial sequence included a very long intracellular domain composed of 716 residues, which seemed by far the longest one found in insect neuroligins.

The complete coding sequence of SlnrxI (KP308210) presented all the characteristic features of insect NRXs (Fig. S3) and more precisely of the isoform A (Biswas et al. 2008). SINRXI N-terminal region corresponded to the large extracellular portion and contained six laminin-G like separated by three EGF (Epidermal Growth Factor) domains. The short intracellular C-terminal part presented a putative PDZ motif "KEWYV" known to bind to various pre-synaptic proteins (Knight et al. 2011). SINRX1 deduced protein presented $86 \%$ of amino acid identity with B mori NRX1 (isoform X2, XP_012544067.1).

Phylogenetic analysis of the inferred protein sequences with D. melanogaster, A. mellifera, Tribolium castaneum and B. mori NLGs was shown in Fig. 1. So far, only lepidopteran species possess six NLGs that include two NLG4 forms. The NLG4 deduced sequence from $S$. littoralis identified here was $83.3 \%$ identical to BmNLG4-YLL (also named BmCCE030c) and only 48\% identical to BmNLG4-XLL, allowing to clearly assign this sequence to the NLG4-YLL clade.

\section{Tissue-related expression of S. littoralis CLAMs}

To determine if the CLAM sequences isolated from the antennal transcriptome were expressed throughout the body or if they presented a more restricted expression pattern, their tissue-related distribution was first qualitatively determined by RT-PCR in various adult male tissues, including antennae of both sexes (Fig. 2). Most of them presented an ubiquitous expression pattern throughout the body. $S \ln \lg 1$ and $\operatorname{S\operatorname {ln}lg} 5$ were faintly expressed in the tested tissues. SlnrxI was amplified in antennae, proboscis and brain but faintly detected in thorax and abdomen. $\operatorname{Sln} \lg 1$ and $\operatorname{Sln} \lg 5$ expression levels were low and despite several attempts using different sets of primers, we were unable to quantify the expression of these transcripts by qPCR 
suggesting very low levels of transcription, even in the brain. However, the expression levels of Slnlg4-yll, SlnrxI, Slnrt and Slgli were sufficient for quantification by qPCR (Fig. 3). Slnlg4-yll highest transcription levels were found in the brain, then in abdomen, proboscis and antennae. SlnrxI expression levels were high in antennae and brain but barely detected in the other tissues tested (Fig 3A). Levels of expression of Slnrt and Slgli were $10^{2}$ lower compared to Slnlg4-yll and SlnrxI (Fig 3B). Slnrt was mostly expressed in the brain, whereas Slgli expression levels were barely detectable in all the tissues tested. For all the studied genes, no sexual dimorphism was observed within the antennae (Fig. 3). In adult moths, such a sexual dimorphism is usually seen in male antennae for olfactory genes involved in female sex pheromone detection (i.e. pheromone receptors, Pheromone-Binding Proteins or PBPs), and in female antennae for genes involved in host plant detection (Poivet et al. 2013), thus absence of such a dimorphism rather suggested a role of the corresponding genes in common functions.

\section{Localization of Slnlg4-yll and SlnrxI expression within antennae}

Within the male antennae, the cellular localization of Slnlg4-yll and Slnrx 1 transcripts was studied by in situ hybridization (Fig. 4). The anatomy of the antennal segment is depicted in Fig 4A. Olfactory sensilla are cuticular structures with an aqueous lumen surrounding the dendrites of the olfactory receptors neurons (ORN). Accessory cells surround the ORN soma. ORNs project their axons to the antennal lobes were the first synapses occur. On longitudinal sections, Slnlg4-yll and SInrxI signals were restricted to the sensilla side, with no labelling on the scale side (Fig 4C, 4E). The olfactory hairs, which are tuned to the detection of odorants in insects, are indeed grouped on the ventral side whereas the dorsal side, without any olfactory function, only bears scales (Ljüngberg et al. 1993). Labelling was associated with cells located at the base of the olfactory hairs (Fig 4D, 4F), within the olfactory epithelium. A similar expression pattern was 
observed for SIPBP1 (Fig. 4B) supposed to be restricted to the olfactory epithelium and supposed to be associated with the accessory cells surrounding the olfactory receptor neurons (ORNs), as for other described PBPs (Steinbrecht et al. 1992). The labelling observed here did not allow a precise identification of the type of labelled cells (ORNs, accessory cells or epidermal cells). The expression levels of the four other CLAMs in antennae were too low to obtain any signal after in situ hybridization, as expected after RT-PCR and qPCR analyses.

\section{Effect of mating on Slnlg4-yll and SlnrxI expression levels}

To test whether Slnlg4-yll and SlnrxI expression could be modulated by the mating status of the males, levels of expression of the corresponding genes in antennae and brains were compared before and after mating (Table 1). After mating, the two transcripts were both significantly increased in the antennae, especially Slnlg4-yll (3.53 fold). In the brain, Slnlg4-yll transcripts showed no difference after mating, whereas $\operatorname{Sln} r x 1$ remained stable. 


\section{Discussion}

We isolated here the homologs of five putative CLAMs, one gliotactin, one neurotactin, three neuroligins and one of their binding-partner, neurexin I in the antennae of a model pest moth. Most insects possess only one gliotactin and one neurotactin, as revealed by genomic/transcriptomic analysis (Oakeshott et al. 2010; Ramsey et al. 2010), suggesting that these two genes have been evolutionary well conserved in insect taxa. Unlike vertebrates which possess three neurexin genes, insects possess only one $n r x I$ (Knight et al. 2011). However, in honeybee, alternative splicing of AmnrxI generates a diversity of variants (Biswas et al. 2008). The number of neuroligins varies from four in D. melanogaster up to six in B. mori (Tsubota and Shiotsuki 2010). In this latter species, two forms of $n \lg 4$ were identified suggesting a recent duplication event that could be common to other Lepidopteran species, as Danaus plexippus (Zhan and Reppert 2013) and Plutella xyllostella (You et al. 2013) also possess two nlg4 isoforms. In S. littoralis antennae, orthologs of $n \lg 1, n \lg 4-y l l$ and $n \lg 5$ were identified. Together with the sequence of glutactin-like (Durand et al. 2012) already isolated in S. littoralis, this leads to six putative non-catalytic CCEs expressed in the olfactory organ of this moth.

Antennal-expressed CLAMs have been previously annotated after transcriptomic analysis only in D. melanogaster (Younus et al. 2014) and in the blowfly Calliphora stygia (Leitch et al. 2015). In these two diptera species, sequences of gliotactin and neurotactin, as well as of two neuroligins, $n \lg 3$ and $n \lg 4$, were identified. However, the expression patterns of these genes were not studied. The diversity of the CLAMs expressed in the adult antennae of these three species raised the question of their possible function in this specialized organ. Insect antennae bear numerous olfactory sensilla tuned to various odorants. These structures consist of one or several ORNs surrounded by three accessory cells, namely the thecogen, trichogen and tormogen cells. 
These cells delimit the sensillar lumen filled with sensillar lymph in which the outer part of the sensory dendrite projects (Keil and Steinbrecht 1987). Axons of all the ORNs are enveloped by glial cells and form the antennal nerve surrounded by hemolymph. The sensillar lymph and the hemolymph have different ionic compositions and septate junctions form a diffusion barrier between these two spaces (Keil and Steinbrecht 1987).

In Drosophila, gliotactin plays a main role in the formation of the glial-based blood-nerve barrier, allowing insulation between nerves and hemolymph (Auld et al. 1995). Electrophysiological analysis of gliotactin mutant embryos revealed that the functioning of the motor neurons was altered with a modification of the synaptic communication pattern, leading to uncoordinated movements (Auld et al. 1995). It has been proposed that gliotactins insulates peripheral motor and sensory axons against the high $\mathrm{K}^{+}$concentration of the hemolymph, which would disturb their excitability. We can suggest a similar role here for Slgli in the antennal septate junctions, participating in sealing off the sensillar lymph against the hemolymph space, a separation required for ORN functioning.

The NLG/NRX complex in vertebrates and invertebrates interacts within the synapse cleft and their intracellular domains bind with numerous PDZ-containing proteins, which in turn interact with transmitter receptors, ion channels and signalling proteins (Biswas et al. 2008; Knight et al. 2011). Interestingly, in the bee, AmnrxI and Amnlgs are also expressed outside the adult brain, and in particular, Amnlgl is more expressed in peripheral tissues than in brain, potentially with a role in the NMJ (Biswas 2008). Significant expression of Amnlgl gene in wings and legs suggested also a putative role in nerve endings responsive to sensory inputs (Biswas et al. 2008). We have here studied in more detail the expression pattern of SlnrxI, together with the most expressed neuroligin Slnlg4-yll within the antennae, showing that both transcripts were mainly expressed at the base of the olfactory sensilla. Surprisingly, such a 
labelling restricted to the olfactory epithelium is usually observed for genes specifically involved in olfactory processes, such as olfactory receptors, odorant-binding proteins or odorant-degrading enzymes (Vogt 2005). However, as there are no synapses at this level of the antennae, this suggested that the $n r x / n l g$ transcripts could be transported up to the axon parts of the ORNs which will form the antennal nerve. Indeed, RNA localization does not necessarily reflect the distribution of the proteins that can be distantly localized on axonal projections, as shown previously for AmnrxI (Biswas et al. 2008). Our result suggested also a putative presynaptic expression for Slnlg4-yll. If many studies showed that NLGs primarily function as postsynaptic adhesion molecules, several exceptions to this localization have been reported and in particular, in Drosophila, dmnlg2 is required both at the pre and postsynaptic level for synapse development and function (Chen et al. 2012). As in situ hybridization was not conclusive with regard to cell type labelled in S. littoralis antennae, one can also hypothesize an expression of these molecules in non-neuronal cells of the sensilla. In vertebrates, NRX and NLGs have been described in nonneuronal cells, suggesting a broader function for this protein complex. They have been for example found in endothelial cells from blood vessels and involved in angiogenesis and in vessel tone control (Bottos et al. 2009; Bottos et al. 2011). In Drosophila photoreceptor cells, nrxI is involved in rhodopsin maturation via mediating retinoid transport (Tian et al. 2013), suggesting a non-synaptic mechanism for neurexin function in this sensory system.

In Drosophila, nrxI mutant larvae are impaired in associating odours with a reward and it has been proposed that nrxI may affect this associative learning by regulating synapse function (Zeng et al. 2007). In the honeybee, sensory deprivation and associative scent training modulated AmnrxI, Amnlg1 and Amnlgn3 expression levels in the brain (Biswas et al. 2010). These results suggested that Amnlg/nrx could be involved in synapse formation during adult neurogenesis, a process required for experience-and age-related plasticity. These Amnlg/nrx expression level 
variations have been interpreted as a consequence of changes in neuronal wiring due to the modification of the olfactory environment (Biswas et al. 2010). However, variations of $n r x / n l g$ in the bee olfactory system were not investigated, and more generally, nrx/nlg expression in insect sensory systems has not been studied, despite these systems are also able to sustain plasticity. In insects, various behaviours are modulated in response to physiological or environmental changes, such as experience, mating, age or time of the day (review in (Martel et al. 2009)). In most species, this behavioural plasticity is mainly sustained by a modulation of the central olfactory system (antennal lobes and mushroom bodies, see e.g. (Anton et al. 2015; Barrozo et al. 2011)). But as antennae are the first place of odorant detection, modulation can also take place at this peripheral level. In the case of S. littoralis, a nocturnal species, most behaviours rely on olfaction. Mating has been shown to modulate the olfactory-driven behaviours, with central and peripheral olfactory system modulations in both females (Martel et al. 2009) (Saveer et al. 2012) and males (Kromann et al. 2015). In male moths, mating temporary abolishes male attraction to females and host plant odours (Kromann et al. 2015). This behavioural modulation is correlated with a decrease of antennal and ORN sensitivity to the sex pheromone (Kromann et al. 2015) but the mechanisms underlying this peripheral plasticity are still unknown. As neurexin/neuroligins have been proposed to participate in sensory synaptic plasticity, we studied here their expression level variations within the antennae. The upregulation of Slnlg4-yll and Slnrx 1 in male antennae observed after mating suggest that these molecules could putatively play a role in peripheral olfactory system plasticity.

Further studies on the expression pattern of these genes within the olfactory organs of insects and their modulation by environmental and physiological cues would bring interesting information on the possible involvement of these molecules in antennal functioning and sensory plasticity. 


\section{Acknowledgements}

We thank M. Solvar for her help in histology and insect rearing. This work was supported by Sorbonne Universités UPMC - Univ Paris 06.

\section{Disclosure}

The authors declare no conflicts of interest. 


\section{References}

Anton, S., Chabaud, M., Schmidt-Büsser, D., Gadenne, C., Iqbal, J., Juchaux, M., List, O., Gaertner, C. and Devaud, J. (2015) Brief sensory experience differentially affects the volume of olfactory brain centres in a moth. Cell Tissue Research, DOI 10.1007/s00441-015-2299-0.

Auld, V., Fetter, R., Broadie, K. and Goodman, C. (1995) Gliotactin, a novel transmembrane protein on peripheral glia, is required to form the blood-nerve barrier in Drosophila. Cell, 81, 757-767.

Bang, M. and Owczarek, S. (2013) A matter of balance: role of neurexin and neuroligin at the synapse. Neurochemical Research, 38, 1174-1189.

Banovic, D., Khorramshahi, O., Owald, D., Wichmann, C., Riedt, T., Fouquet, W., Tian, R., Sigrist, S. and Aberle, H. (2010) Drosophila neuroligin 1 promotes growth and postsynaptic differentiation at glutamatergic neuromuscular junctions. Neuron, 66, 724-738.

Barrozo, R., Jarriault, D., Deisig, N., Gemeno, C., Monsempes, C., Lucas, P., Gadenne, C. and Anton, S. (2011) Mating-induced differential coding of plant odour and sex pheromone in a male moth European Journal of Neuroscience, 33, 1841-1850.

Barthalay, Y., Hipeau-Jacquotte, R., de la Escalera, S., Jimenez, F. and Piovant, M. (1990) Drosophila neurotactin mediates heterophilic cell adhesion. EMBO Journal, 9, 3603-3609.

Baumgartner, S., Littleton, J., Broadie, K., Bhat, M., Harbecke, R., Lengyel, J., ChiquetEhrismann, R., Prokop A. and Bellen, H.J. (1996) A Drosophila neurexin is required for septate junction and blood-nerve barrier formation and function. Cell, 87, 1059-1068.

Bigot, L., Shaik, H., Bozzolan, F., Party, V., Lucas, P., Debernard, S. and Siaussat, D. (2011) Peripheral regulation by ecdysteroids of olfactory responsiveness in male Egyptian cotton leaf worms, Spodoptera littoralis. Insect Biochemistry and Molecular Biology, 42, 22-31.

Biswas, S., Reinhard, J., Oakeshott, J., Russell, R., Srinivasan, M. and Claudianos, C. (2010) Sensory regulation of neuroligins and neurexin I in the honeybee brain. PLoS One, 5(2), e9133.

Biswas, S., Russell, R.J., Jackson, C.J., Vidovic, M., Ganeshina, O., Oakeshott, J.G. and Claudianos, C. (2008) Bridging the Synaptic Gap: Neuroligins and Neurexin I in Apis mellifera PLoS One, 3(10), e3542.

Bottos, A., Destro, E., Rissone, A., Graziano, S., Cordara, G., Assenzio, B., Cera, M., Mascia, L., Bussolino, F. and Arese, M. (2009) The synaptic proteins neurexins and neuroligins are widely expressed in the vascular system and contribute to its functions. Proceedings of the National Academy of Sciences, 106, 20782-20787.

Bottos, A., Rissone, A., Bussolino, F. and Arese, M. (2011) Neurexins and neuroligins: synapses look out of the nervous system. Cellular and Molecular Life Sciences, 68, 2655-2666.

Chen, Y., Lin, Y., Banerjee, S., Venken, K., Li, J., Ismat, A., Chen, K., Duraine, L., Bellen, H. and Bhat, M. (2012) Drosophila neuroligin 2 is required presynaptically and postsynaptically for proper synaptic differentiation and synaptic transmission. Journal of Neuroscience, 32, 16018-16030.

Durand, N., Carot-Sans, G., Bozzolan, F., Rosell, G., Siaussat, D., Debernard, S., Chertemps, T. and Maïbèche-Coisne, M. (2011) Degradation of pheromone and plant volatile components by a same Odorant-Degrading Enzyme in the cotton leafworm, Spodoptera littoralis. PLoS One, 6(12), e29147. 
Durand, N., Carot-Sans, G., Chertemps, T., Bozzolan, F., Party, V., Renou, M., Debernard, S., Rosell, G. and Maïbèche-Coisne, M. (2010a) Characterization of an antennal carboxylesterase from the pest moth Spodoptera littoralis degrading a host plant odorant. PLoS One, 5(11), e15026.

Durand, N., Carot-Sans, G., Chertemps, T., Montagné, N., Jacquin-Joly, E., Debernard, S. and Maïbèche-Coisne, M. (2010b) A diversity of putative carboxylesterases is expressed in the antennae of the noctuid moth Spodoptera littoralis. Insect Molecular Biology, 19(1), 87-97.

Durand, N., Chertemps, T. and Maïbèche-Coisne, M. (2012) Antennal carboxylesterases in a moth, structural and functional diversity. Communicative and Integrative Biology, 5, 284-286.

Frémion, F., Darboux, I., Diano, M., Hipeau-Jacquotte, R., Seeger, M. and Piovant, M. (2000) Amalgam is a ligand for the transmembrane receptor neurotactin and is required for neurotactin-mediated cell adhesion and axon fasciculation in Drosophila. EMBO Journal, 19, 4463-4472.

Gilbert, M. and Auld, V. (2005) Evolution of clams (cholinesterase-like adhesion molecules): structure and function during development. Frontiers in Bioscience, 10, 2177-2192.

Guerrieri, F., Gemeno, C., Monsempes, C., Anton, S., Jacquin-Joly, E. and Lucas, P., Devaud J.M. (2012) Experience-dependent modulation of antennal sensitivity and input to antennal lobes in male moths (Spodoptera littoralis) pre-exposed to sex pheromone. Journal of Experimental Biology, 215, 2334-2341.

Jacquin-Joly, E., Legeai, F., Montagné, N., Monsempes, C., François, M., Poulain, J., Gavory, F., Walker, W., Hansson, B. and Larsson, M. (2012) Candidate chemosensory genes in female antennae of the noctuid moth Spodoptera littoralis. International Journal of Biological Sciences, 8, 1036-1050.

Johnson, G. and Moore, S. (2013) The Leu-Arg-Glu (LRE) adhesion motif in proteins of the neuromuscular junction with special reference to proteins of the carboxylesterase/cholinesterase family. Comparative Biochemistry and Physiology Part D: Genomics and Proteomics, 8, 231-243.

Keil, T.A. and Steinbrecht, R.A. (1987) Diffusion barriers in silkmoth sensory epithelia: application of lanthanum tracer to olfactory sensilla of Antheraea polyphemus and Bombyx mori. Tissue and Cell,19, 119-134.

Knight, D., Xie, W. and Boulianne, G. (2011) Neurexins and neuroligins: recent insights from invertebrates. Molecular Neurobiology, 44, 426-440.

Kromann, S., Saveer, A., Binyameen, M., Bengtsson, M., Birgersson, G., Hansson, B., Schlyter, F., Witzgall, P., Ignell, R. and Becher, P. (2015) Concurrent modulation of neuronal and behavioural olfactory responses to sex and host plant cues in a male moth. Proceedings of the Royal Society B: Biological Sciences, 282, 20141884.

Kumar, S., Tamura, K. and Nei, M. (2004) MEGA3: Integrated software for Molecular Evolutionary Genetics Analysis and sequence alignment. Briefings in Bioinformatics, 5, 150163.

Larkin, A., Chen, M., Kirszenblat, L., Reinhard, J., van Swinderen, B. and Claudianos, C. (2015) Neurexin-1 regulates sleep and synaptic plasticity in Drosophila melanogaster. European Journal of Neuroscience, 42, 2455-2466.

Leal, W. (2013) Odorant reception in insects: roles of receptors, binding proteins, and degrading enzymes. Annual Review of Entomology, 58, 373-391.

Legeai, F., Malpel, S., Montagné, N., Monsempes, C., Cousseran, F., Merlin, C., François, M.-C., Maïbèche-Coisne, M., Gavory, F., Poulain, J. and Jacquin-Joly, E. (2011) An Expressed 
Sequence Tag collection from the male antennae of the Noctuid moth Spodoptera littoralis: a resource for olfactory and pheromone detection research. BMC Genomics, 12:86

Leitch, O., Papanicolaou, A., Lennard, C., Kirkbride, K. and Anderson, A. (2015) Chemosensory genes identified in the antennal transcriptome of the blowfly Calliphora stygia. BMC Genomics, 16: 255.

Li, J., Ashley, J., Budnik, V. and Bhat, M. (2007) Crucial role of Drosophila neurexin in proper active zone apposition to postsynaptic densities, synaptic growth, and synaptic transmission. Neuron, 55, 741-755.

Li, Y., Zhou, Z., Zhang, X., Tong H., Li, P., Zhang, Z., Jia, Z., Xie, W. and Han, J. (2013) Drosophila neuroligin 4 regulates sleep through modulating GABA transmission. Journal of Neuroscience, 33, 15545-15554.

Ljüngberg, H., Anderson, P. and Hansson, B. (1993) Physiology and morphology of pheromonespecific sensilla on the antennae of male and female Spodoptera littoralis (Lepidoptera: Noctuidae). Journal of Insect Physiology, 39, 253-260.

Martel, V., Anderson, P., Hansson, B. and Schlyter, F. (2009) Peripheral modulation of olfaction by physiological state in the Egyptian leaf worm Spodoptera littoralis (Lepidoptera: Noctuidae). Journal of Insect Physiology, 55, 793-797.

Merlin, C., Lucas, P., François, M.C., Maïbèche-Coisne, M. and Jacquin-Joly, E. (2007) Antennal circadian clock and circadian rhythms in the peripheral pheromone reception in the moth Spodoptera littoralis. Journal of Biological Rhythms, 22, 502-514.

Mozer, B.A. and Sandstrom, D.J. (2012) Drosophila neuroligin 1 regulates synaptic growth and function in response to activity and phosphoinositide-3-kinase. Molecular and Cellular Neuroscience, 51, 89-100.

Oakeshott, J.G., Claudianos, C., Campbell, P., Newcomb, R. and Russell, R. (2005) Biochemical genetics and genomics of insect esterases. In: Comprehensive Molecular Insect Science (Eds L. Gilbert, K. Iatrou, \& S. Gill). Vol. 5, pp. 309-381. Elsevier, Oxford.

Oakeshott, J.G., Johnson, R.M., Berenbaum, M.R., Ranson, H., Cristino, A.S. and Claudianos, C. (2010) Metabolic enzymes associated with xenobiotic and chemosensory responses in Nasonia vitripennis. Insect Molecular Biology, 119, 147-163.

Olson, P., Fessler, L., Nelson, R., Sterne, R., Campbell, A. and Fessler, J. (1990) Glutactin, a novel Drosophila basement membrane-related glycoprotein with sequence similarity to serine esterases. EMBO Journal, 9, 1219-1227.

Poivet, E., Gallot, A., Montagné, N., Glaser, N., Legeai, F. and Jacquin-Joly, E. (2013) A comparison of the olfactory gene repertoires of adults and larvae in the noctuid moth Spodoptera littoralis. PLoS One, 8, e60263.

Ramsey, J., Rider, D., Walsh, T., De Vos, M., Gordon, K., Ponnala, L., Macmil, S., Roe, B. and Jander, G. (2010) Comparative analysis of detoxification enzymes in Acyrthosiphon pisum and Myzus persicae. Insect Molecular Biology, 19, 155-64.

Saveer, A., Kromann, S., Birgersson, G., Bengtsson, M., Lindblom, T., Balkenius, A., Hansson, B., Witzgall, P., Becher, P. and Ignell, R. (2012) Floral to green: mating switches moth olfactory coding and preference. Proceedings of the Royal Society B: Biological Sciences, 279, 2314-2322.

Schulte, J., Tepass, U. and Auld, V. (2003) Gliotactin, a novel marker of tricellular junctions, is necessary for septate junction development in Drosophila. Journal of Cell biology, 161, 9911000 .

Simon, P. (2003) Q-gene: processing quantitative real-time RT-PCR data. Bioinformatics, 19, $1439-1440$. 
Steinbrecht, R., Ozaki, M. and Ziegelberger, G. (1992) Immunocytochemical localization of pheromone-binding protein in moth antennae. Cell and Tissue Research, 270, 287-302.

Sun, M. and Xie, W. (2012) Cell adhesion molecules in Drosophila synapse development and function. Science China Life Sciences, 55, 20-26.

Sun, M., Xing, G., Yuan, L., Gan, G., Knight, D., With, S., He, C., Han, J., Zeng, X., Fang, M., Boulianne, G. and Xie, W. (2011) Neuroligin 2 is required for synapse development and function at the Drosophila neuromuscular junction. Journal of Neuroscience, 31, 687-699.

Teese, M., Campbell, P., Scott, C., Gordon, K., Southon, A., Hovan, D., Robin, C., Russell, R. and Oakeshott, J.G. (2010) Gene identification and proteomic analysis of the esterases of the cotton bollworm, Helicoverpa armigera. Insect Biochemistry and Molecular Biology, 40, 116.

Tian, Y., Li, T., Sun, M., Wan, D., Li, Q., Li, P., Zhang, Z., Han, J. and Xie, W. (2013) Neurexin regulates visual function via mediating retinoid transport to promote rhodopsin maturation. Neuron, 77, 311-322.

Tsubota, T. and Shiotsuki, T. (2010) Genomic analysis of carboxyl/cholinesterase genes in the silkworm Bombyx mori. BMC Genomics, 11, 377-387.

Vogt, R.G. (2005) Molecular basis of pheromone detection in insects. In: Comprehensive Insect Physiology, Biochemistry, Pharmacology and Molecular Biology (Eds L. Gilbert, K. Iatrou, K \& S. Gill). Vol. 3, pp. 753-804. Elsevier, London.

Xing, G., Gan, G., Chen, D., Sun, M., Yi, J., Lv H., Han, J. and Xie, W. (2014) Drosophila neuroligin 3 regulates neuromuscular junction development and synaptic differentiation. Journal of Biological Chemistry, 289, 31867-31877.

You, M., Yue, Z., He, W., Yang, X., Yang, G. et al. (2013) A heterozygous moth genome provides insights into herbivory and detoxification. Nature Genetics, 45, 220-225.

Younus, F., Chertemps, T., Pearce, S., Pandey, G., Bozzolan, F., Coppin, C., Russell, R., Maïbèche-Coisne, M. and Oakeshott, J.G. (2014) Identification of candidate odorant degrading gene/enzyme systems in the antennal transcriptome of Drosophila melanogaster. Insect Biochemistry and Molecular Biolology, 53, 30-43.

Zeng, X., Sun, M., Liu, L., Chen, F., Wei, L. and Xie, W. (2007) Neurexin-1 is required for synapse formation and larvae associative learning in Drosophila. FEBS Letters, 581, 25092516.

Zhan, S. and Reppert, S. (2013) MonarchBase: the monarch butterfly genome database. Nucleic Acids Research, 41, D758-63. 


\section{Legends of the figures}

Figure 1: Diversity of antennal CLAMs in S. littoralis. Neighbor-joining tree of the antennal CLAMs from S. littoralis and various insects. S. littoralis sequences are in bold and red, D. melanogaster in blue, A. mellifera in green, Tribolium castaneum in black and B. mori in orange. GenBank accession numbers are indicated under brackets. Nodes with bootstrap values less than $50 \%$ were collapsed.

Figure 2: $S$. littoralis CLAMs present an ubiquitous expression pattern throughout the body. Qualitative analysis of $S$. littoralis CLAM expression throughout different body parts by RTPCR.

Figure 3: Expression of Slnlg4-yll, SlnrxI (A) and Slnrt, Slgli (B) in S. littoralis tissues by quantitative PCR (qPCR). $\hat{\jmath}$ Ant: male antennae ; $q$ Ant: female antennae ; Prob: proboscis ; Tho: thorax ; Abd: abdomen. Data were obtained from triplicate experiments and are given as the mean $+/-$ SD.

Figure 4: $\operatorname{Sln} \lg 4-y l l$ and $\operatorname{Sln} r x 1$ are associated with olfactory sensilla. Expression patterns of Slnlg4-yll (C, D) and Slnrxl (E, F) after in situ hybridization on longitudinal sections of $S$. littoralis male antennae. (A) Global view of an antennal segment, showing the disposition of the olfactory epithelium (1), the antennal lumen filled with hemolymph (2), the trachea (3), the antennal nerve (4), , and the epidermis (5). Arrowheads indicate some olfactory sensilla. (B) SIPBP1 positive control. (D, F) Higher magnifications of olfactory epithelium showing labelling at the base of the olfactory sensilla. Scale bars: $25 \mu \mathrm{m}$. 
Table 1 Expression levels of Slnlg4-yll and SlnrxI in male antennae and brains before and after mating, as measured by qPCR.

\begin{tabular}{cccc}
\hline Tissue & Reproductive status & \multicolumn{2}{c}{ Expression relative to SIrp/13 $\left(\mathbf{x ~ 1 0 ^ { - 4 } )}\right.$} \\
\hline \multirow{2}{*}{ Antennae } & Virgin & SInlg4-yll & \multicolumn{1}{c}{ SInrx 1} \\
& Mated & $0.49( \pm 0.14)$ & $53.59( \pm 7.20)$ \\
& & $1.73( \pm 0.41) 3.53$ fold $\uparrow * *$ & $93.00( \pm 20.19) 1.73$ fold $\uparrow * *$ \\
Brain & Virgin & $13.46( \pm 2.13)$ & $92.10( \pm 10.68)$ \\
& Mated & $11.40( \pm 0.82) 0.84$ fold $\downarrow$ & $94.16( \pm 22.06) 1.02$ fold $\rightarrow$ \\
\hline
\end{tabular}

The expression levels of Slnlg4-yll and SlnrxI were normalized to that of Slrpl13 transcript, which was measured in the same cDNAs. Data were obtained from triplicate experiments and are given as the mean normalized expression $+/-$ SD and fold changes. Stars indicate significant difference between the two conditions $(* *: \mathrm{P}<0.01)$. 


\section{Supplemental data}

Figure S1: Alignment of $A$. mellifera, B. mori and S. littoralis neuroligins 4 . The sequences of honeybee and silkworm were taken from NCBI (AmNLG4: NP_001139209; BmNLG4-Y-linkedlike: XP_004924474; SINLG4 KP308206). The alignment was performed using BioEdit with ClustalW. The signal peptide and transmembrane domain were predicted with SignalP 4.1 and TMHMM 2.0. Sequence depicted as the carboxyl/cholinesterase domain was found using the NCBI Conserved Domain Architecture Retrieval Tool. The oxyanion hole, nucleophilic elbow and critical elements of the catalytic triad are highlighted by light blue shading and the LER adhesion motif is in yellow. Asparagines predicted by NetNGlyc 1.0 to be N-glycosylated (jury 9/9) are highlighted in red. Serines predicted by NetPhos 2.0 to be phosphorylated (score $>0.99$ ) are highlighted in purple. TMD: transmembrane domain; PDZ: PDZ (Postsynaptic density 95/Discs large/Zona occludens 1) binding motif; Am: Apis mellifera; Bm: Bombyx mori; Sl: Spodoptera littoralis.

Figure S2: Alignment of $A$. mellifera, B. mori and $S$. littoralis neuroligins 5. (AmNLG5: NP_001139211; BmNLG5: XP_004929129; SINLG5: KP308207). Details as in figure S1.

Figure S3: Alignment of A. mellifera, B. mori and S. littoralis neurexin I.

(AmNrxI: ACM48184; BmNrxI: XP_004924111, SINrxI: KP308210). The signal peptide and transmembrane domain were predicted with SignalP 4.1 and TMHMM 2.0. Sequence depicted as the Laminin G-like and EGF domains were found using the NCBI Conserved Domain Architecture Retrieval Tool except the second EGF domain that was identified in (Biswas et al. 2008). Asparagines predicted by NetNGlyc 1.0 to be N-glycosylated are highlighted in red. 
Serines and threonines predicted by NetOGlyc 4.0 to be O-glycosylated are highlighted in green. Serines predicted by NetPhos 2.0 to be phosphorylated are highlighted in purple. EGF: Epidermial Growth Factor motif.

Table S1: List of the primers used for PCR, quantitative PCR (qPCR) and probe synthesis for in situ hybridization, indicating their sequences and annealing temperatures (Temp.). 


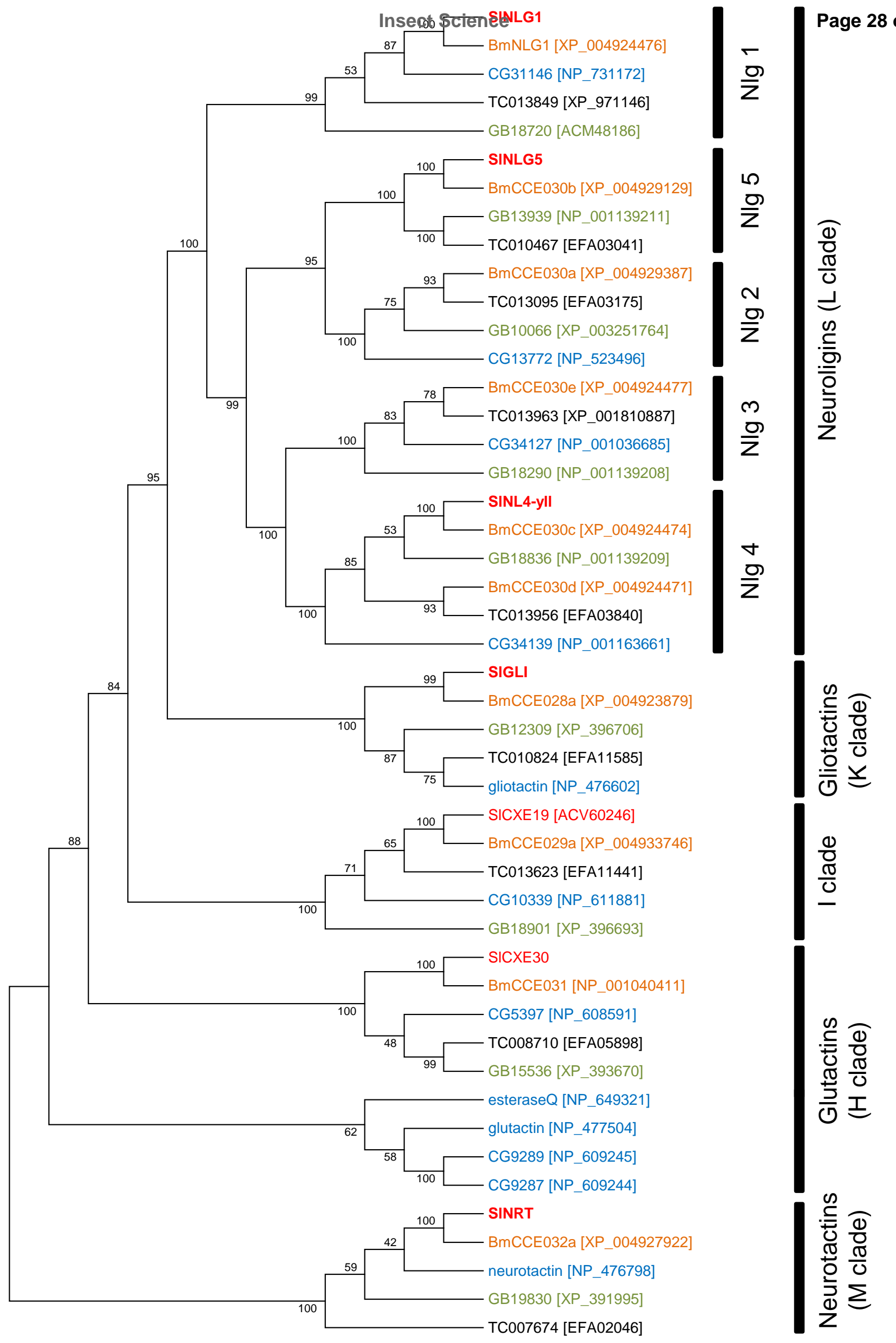




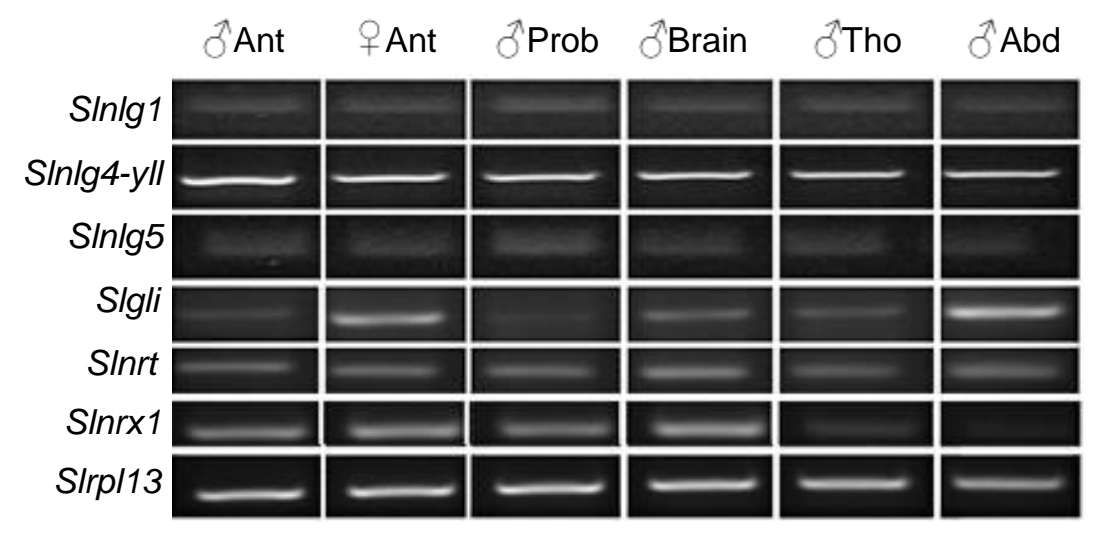




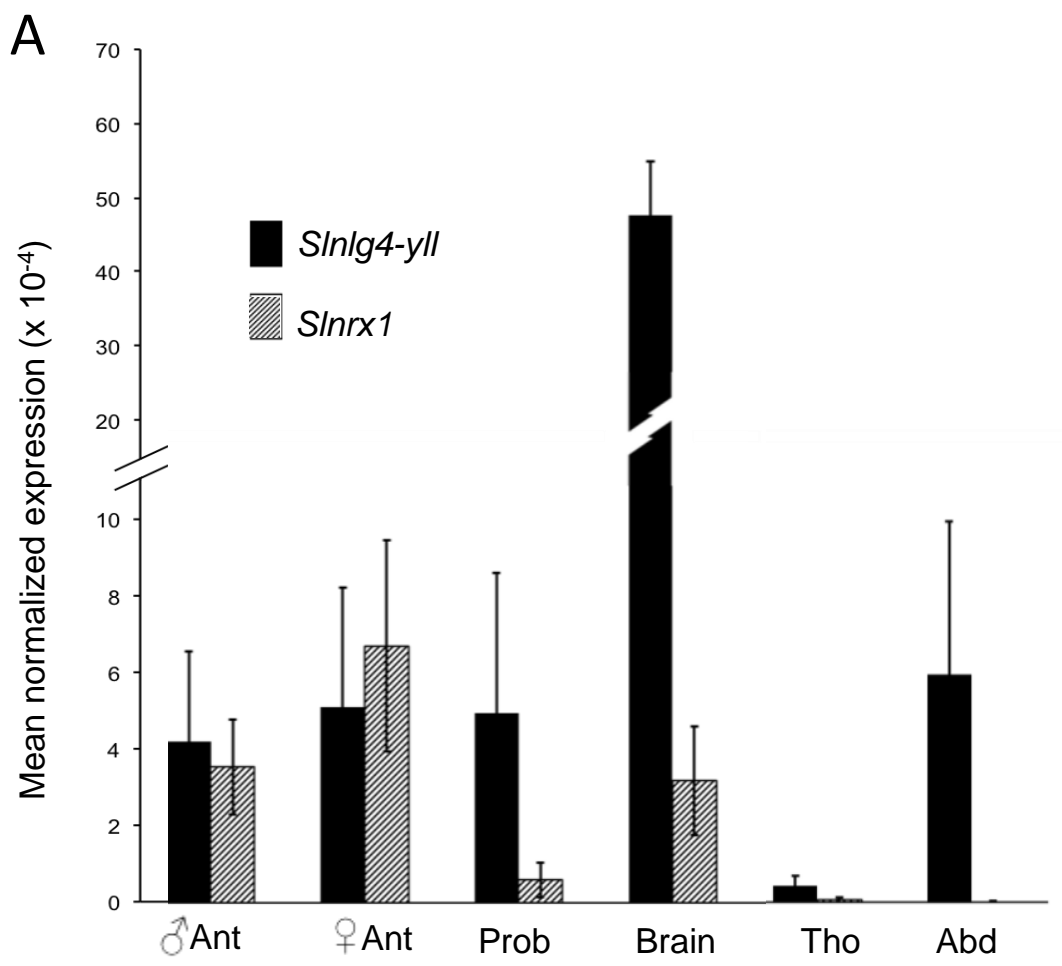

B

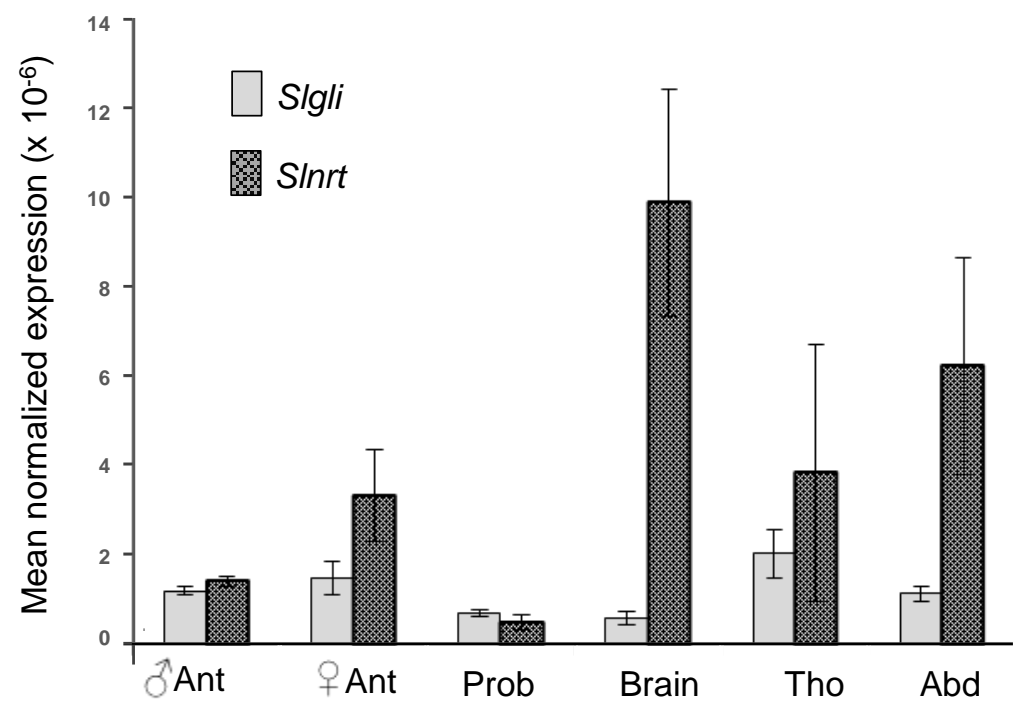




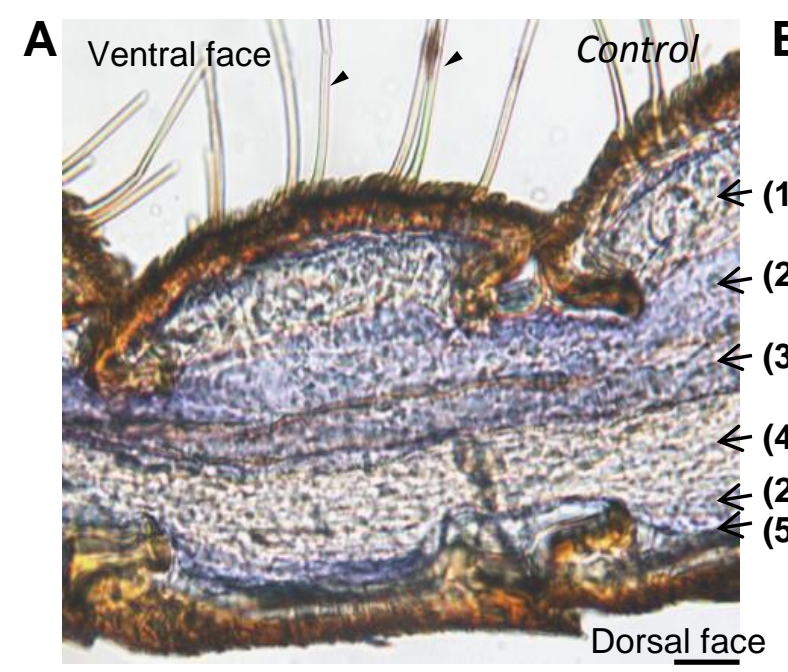

B $\quad S I P B P 1$

C
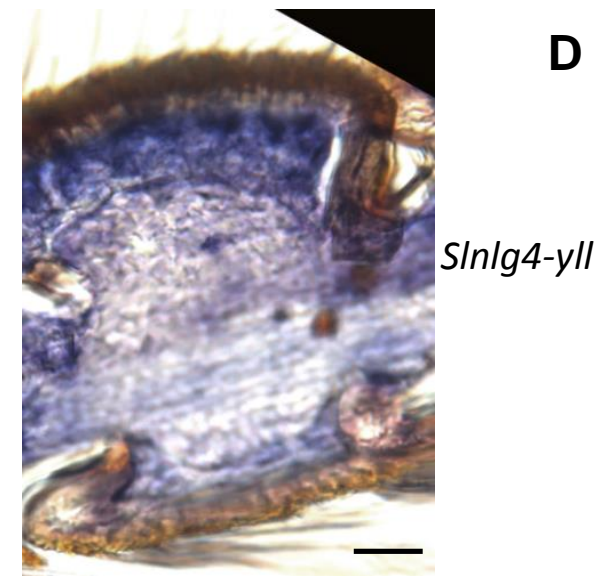

(4)

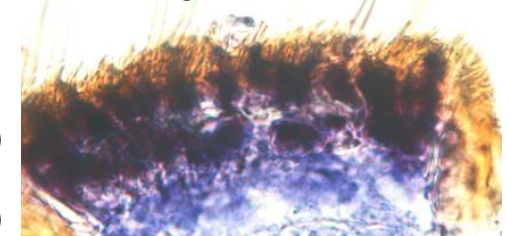

(2)

(3)

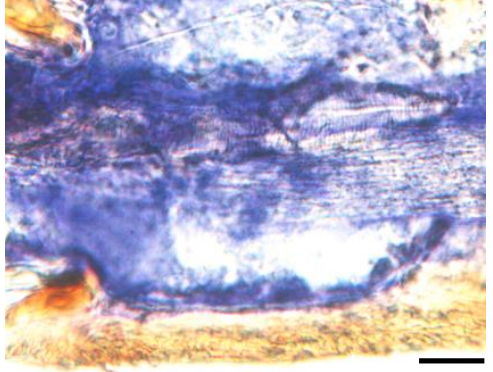

(5)

D

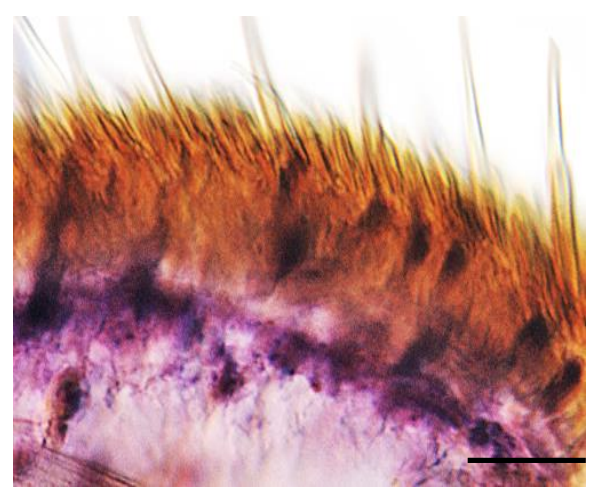

E
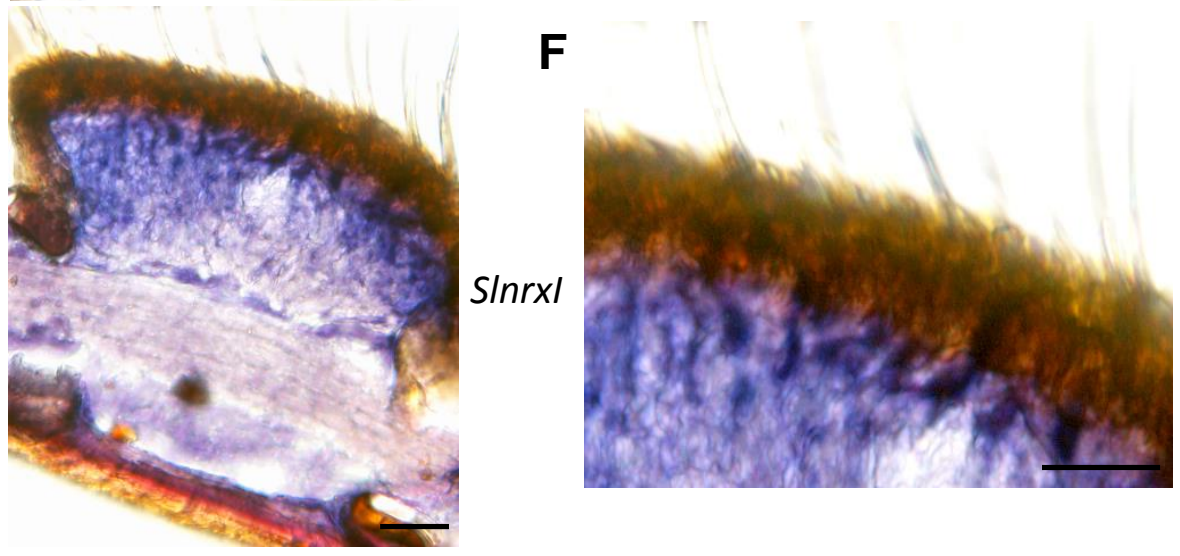


\begin{tabular}{|c|c|c|c|}
\hline Primer & Purpose & Sequence $5^{\prime}-3^{\prime}$ & $\operatorname{Temp}\left({ }^{\circ} \mathrm{C}\right)$ \\
\hline SINLG1-F & RT-PCR/ qPCR & AGGGACTGGATTGCCAATGA & $60^{\circ} \mathrm{C}$ \\
\hline SINLG1-R & RT-PCR/ qPCR & AGAGCCAAGCGCTGAAGTA & $60^{\circ} \mathrm{C}$ \\
\hline SINLG4-yll-F & RT-PCR / qPCR & ACTCACCGCCTTTTGCAAGAGTTAC & $60^{\circ} \mathrm{C}$ \\
\hline SINLG4-yll-R & RT-PCR / qPCR & GCAGAGTCAGATGGGATTAACCGT & $60^{\circ} \mathrm{C}$ \\
\hline SINLG5-F & RT-PCR/ qPCR & TGTTCGCCGGCATCTACCT & $60^{\circ} \mathrm{C}$ \\
\hline SINLG5-R & RT-PCR/ qPCR & TGCGCTTGAGCGTGCTCTT & $60^{\circ} \mathrm{C}$ \\
\hline SINRT-F & RT-PCR/ qPCR & GAAGCAAATTGAGGCTGAGGA & $60^{\circ} \mathrm{C}$ \\
\hline SINRT-R & RT-PCR/ qPCR & TTCACTTCACGGCCCATCT & $60^{\circ} \mathrm{C}$ \\
\hline SIGLI-F & RT-PCR/ qPCR & TGCCTAGTCCAGGTGACAGTGA & $60^{\circ} \mathrm{C}$ \\
\hline SIGLI-R & RT-PCR/ qPCR & ACCAGGGAATAAGGCATCTGGGTT & $60^{\circ} \mathrm{C}$ \\
\hline SINrxI-F & RT-PCR / qPCR & TCCGAGGGCTGGAACCGACC & $60^{\circ} \mathrm{C}$ \\
\hline SINrxI-R & $\mathrm{RT}-\mathrm{PCR} / \mathrm{qPCR}$ & AGTTCCTCAGTTTGCGTTATATGTTCAGG & $60^{\circ} \mathrm{C}$ \\
\hline SINrxI-ORF-F1 & ORF cloning & ATGCCCTCCGACGTCG & $58^{\circ} \mathrm{C}$ \\
\hline SINrxI-ORF-R1 & ORF cloning & TCAGGGTGGAAAAGTCCTCCT & $58^{\circ} \mathrm{C}$ \\
\hline SINrxI-ORF-F2 & ORF cloning & CGACACTTGGCATACGGTG & $58^{\circ} \mathrm{C}$ \\
\hline SINrxI-ORF-R2 & ORF cloning & CACGTACCACTCTTTGATGCC & $58^{\circ} \mathrm{C}$ \\
\hline SINLG1-5' & $3^{\prime}$ RACE-PCR & TTGGCAATCCAGTCCCTCACTTTAGTGT & $68^{\circ} \mathrm{C}$ \\
\hline SINLG1-3' & $3^{\prime}$ RACE-PCR & CACTAAAGTGAGGGACTGGATTGCCAATGA & $68^{\circ} \mathrm{C}$ \\
\hline SINLG4-yll-5' & 5'RACE-PCR & AACCCATCTGCGGGTAGCTCACGTTA & $68^{\circ} \mathrm{C}$ \\
\hline SINLG5-5 & 5'RACE-PCR & GGAGAGGTTACAGAAGTCGGCTCGTTGCT & $68^{\circ} \mathrm{C}$ \\
\hline SINRT-3' & $3^{\prime}$ RACE-PCR & TGGAGAACATCGAGCCTGCGGAGTTG & $68^{\circ} \mathrm{C}$ \\
\hline SINLG4-yll-HIS-F & In situ hybridization & CGACACAGCCCTAACGACTGTTGA & $60^{\circ} \mathrm{C}$ \\
\hline SINLG4-yll-HIS-R & In situ hybridization & САСTCTCATTTCGTCAATGGCGGCT & $60^{\circ} \mathrm{C}$ \\
\hline SINrxI-HIS-F & In situ hybridization & CGAAAACGCTTGGAGTCGGAACTA & $54^{\circ} \mathrm{C}$ \\
\hline SINrxI-HIS-R & In situ hybridization & TCCAGACTGGACATGCATCCTTCA & $54^{\circ} \mathrm{C}$ \\
\hline SIPBPI-HIS-R & In situ hybridization & ATGGCGAAGGAAGTTGGACC & $55^{\circ} \mathrm{C}$ \\
\hline SIPBPI-HIS-f & In situ hybridization & CTCGTCGATCTTAGTGCGGA & $55^{\circ} \mathrm{C}$ \\
\hline
\end{tabular}

Table S1: List of the primers used for PCR, quantitative PCR (qPCR) and probe synthesis for in situ hybridization, indicating their sequences and annealing temperatures (Temp.). 
Figure S1: Neuroligin 4 Multiple Alignment

\section{Signal peptide}

10

20

30

40

50

60

70

80

90

100

BmNLG4 -YLI SINLG4-YLI

-----------------------------------------MQNDQPS MFNHVPLSAHIKYPTQQLVFFNIYFILVVTCLSADTVNS

NYDDHDREHDPVDYAKVNFDHNPFFNSEDFLQ-

Carboxyl cholinesterase domain

110

120

130

140

150

160

170

180

190

200

AmNLG4
BmNLG4-YLI

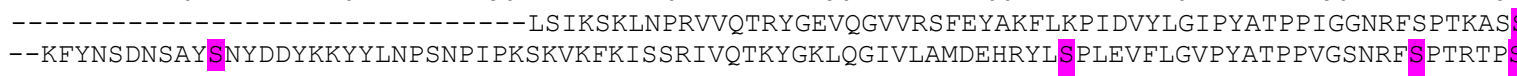

LEVFLGVPYATPPVGSNRESPTR

210

220

230

240

250

260

270

280

290

300

AmNLG4

SINLG4-YLI

SVGPVCPOKLPDI SNEOEALERMPKGRLEYLKRLLPHLRNOSEDCLYLNIYAPAMGMADNNSRKHPVLLYIHGESYDWGSGNPYDGSVLASYTDOVIVTM RPGPACPQTLPDIEDERTILEKMPKGRLEYLKRLMPYLKNQSEDCLYLNIFAPLQ--MDETKLELPVLVYIHGESYSWSSSHPYDGAVLASYTDLIVVTL RPGPACPQKLPDMDDERTILEKMPKGRLEYMKRLI PYLKNQSEDCLYLNIFAPLQ--MDETKLALPVLVY IHGESYSSSSSHPYDGAVLASYTDLIVVTL

320

330

340

350

360

370

380

390

400

AmNLG4

SINLG4 - YLL

AmNLG4

NYRLGVLGFLNANMAPQTKARVANYGLMDQIAALQWVNEHIALFGGDPN NFRLGVLGFLNANPAPHLKARVANYGLMDQIAALHWVQQNIALFGGDPTNITLMGHGSGAACINFLMISPTVMPGLFHRAILLSGSALSSWAIVDDPVYY

NVTLMGQGTGAACVHFLAISPTVVRGLFKRAILLSGSALSSWAVVEDPVSY

420

430

440

450

460

470

480

490

500

ALKLAKAVNCTIPNDLFKNNELIVDCLRDRSLEELMKVNIQPPTELSAFGPSVDGVVIKPDFQKDLLSYMGP-EFQGFGPLP---------KKAEHGAPI SLKLAKHMNCTVPEDLSKDHEVIVDCLREAS IRDLLAADISPPNYLTAFGPSVDGVVIKTDFGKDFLTMYSTGDFPSFGPLNNMNFNFNVHKKRSDSGRR SLKLAKHMNCSI PDDLSKDHEVIVDCLREATIEELLSADISPPNFLTAFGPSVDGVVIKTDFAKDFLTMYSTGDFPSFGPLNNMN INLNVHKKRSDSGRR

\begin{tabular}{lcccccccc} 
& EF hand metal binding & & \multicolumn{2}{c}{ EF hand metal binding } \\
\hline 510 & 520 & 530 & 540 & 550 & 560 & 570 & 580 & $590 \quad 600$
\end{tabular}

AmNLG4 TSNNKYDLLFGVTTSEALWKFAERDVQQGFEGERRDRI IRTYVRNAYVYHLTEIFYTVVNEYTDWERTVQHPVNTKDACVQALSDAQFVAPLVQTGDLFT

\section{TMD}

$870 \quad 880$

890

900

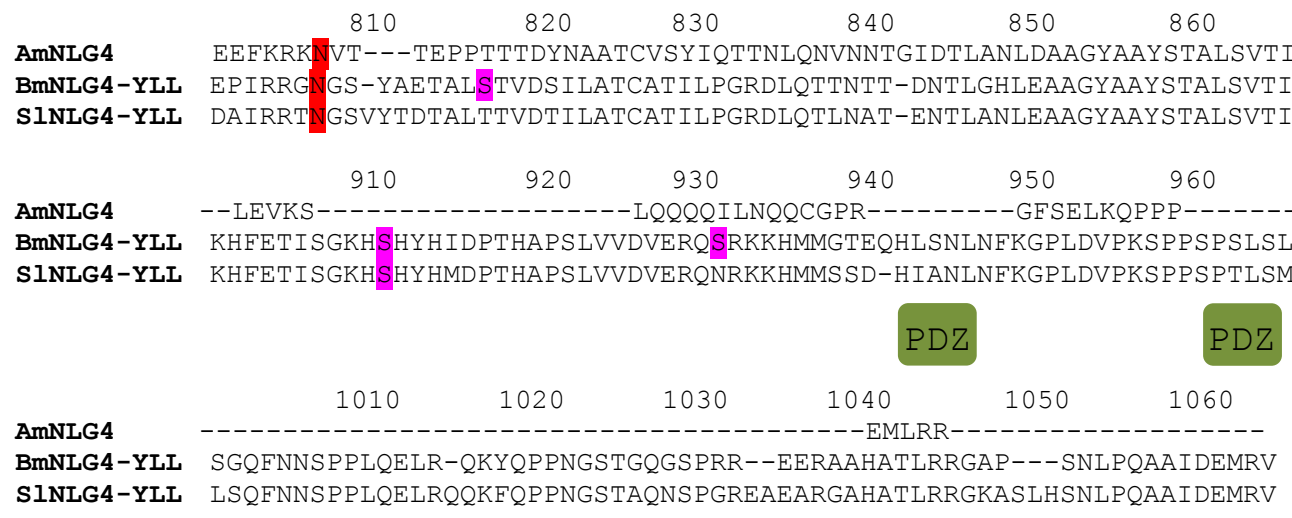
AmNLG4
EPIRRG
920
$930 \quad 940$
QQQQILNQQCGPR---------4
AmNLG4 KHEETISGK SHYH 920
$-1----L Q Q Q Q I L N$
THAPSLVVDVERQSRKK BMNLG4-YLL SGQFNNSPPLQELR-QKYQPPNGSTGQGSPRR--EERAAHATLRRGAP---SNLPQAAIDEMRV SINLG4-YLL LSQFNNSP PLQELRQQKFQPPNGSTAQNSPGREAEARGAHATLRRGKASLHSNLPQAAIDEMRV

GCSLLILNVLIFAGVYYQRDKTR

RSRGKQHRFNE 980 990

1000 


\section{Figure S2: Neuroligin 5 Multiple Alignment}

AmNLG5 BmNLG5 SINLG5

AmNLG5

BmNLG5

SINLG5

AmNLG5

BmNLG5

SINLG5

AmNLG5

BmNLG5

SINLG5

AmNLG5

BmNLG5

SINLG5

AmNLG5

BmNLG5

SINLG5

AmNLG5

BmNLG5

SINLG5

AmNLG5

BmNLG5

SINLG5

\section{Signal peptide}

10

20

30

50

Carboxyl cholinesterase domain

MPLPCQPAARKRPLATRSSSGSRTCLALI IAIVLLGRRGSRAATQIRYASRIVETKSGQIRGILQDLNSKHLDPVEVFRGI PYAAPPVGDLRFRPPISPI --MECL--------------WRWCAALVLATL------AAA--GPRYSSRIVHTHTGAIRGI IVEPASRRLEPVEVFLGVPYAGPPP---RLGVPPAPP --MDCLRTA----------WCWCAALVLATL------AAA--GPRYSSRIVHTHAGA IRGI IVEPASRRLEPVEVFLGVPYAGAPA---RLAPPPPAP

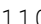

120

130

140

160

170

180

190

200

PWDGIKLADSFGAVCPQHFPDISNDTAALLQMPLGRYQQLKRLYMFLT GWSGTRLADAFAPVCPQRYPDISNKSAALSNMPLGIYNELKATVPMLA SWPGTRLADAFAPVCPQRYPDISNKSAALAKMPLGIYNELRATVPLI

OSEDCLFLNLYIPGSGSRGLEAPYAVMAYVHGESFEWGTGNIYDGSVLASA QSEDCLFLNIYVPGSGARGVEAPYAVVMWLGAPSHEWGSANTLDGAVLAAR QSEDCLYLNIYVPGSGARGVEAPYAVVVWAGGPS HEWGTANALDGAVLAAR

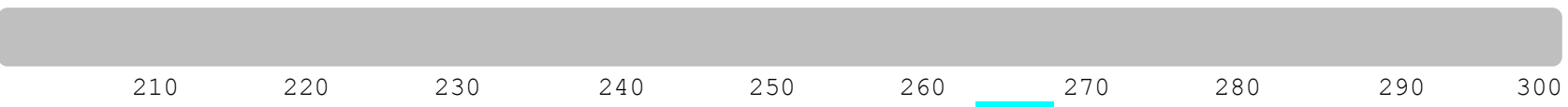
GHVIVITLNYRLGILGFLRTRPYPDRTPGSGGNLALKDIAMGLRWVRENIAAFGGDPTKITLIGHDTGAALVNLLLLAPYGKGLFHRVVLSSGSALSPWA AHLLVITVNYRIGLLGYLTTGLNTDPVQQAGG-SAQLDVAAALGWVRRNVAAFGGDARRLTLAGHAAGAALANAMLMMPDTKGLVSRVLLLSGSALSPTA AHLLVVTINYRLGLLGYLTPGVRSTAVQAAGG-AAVLDVAAALGWVRRNVASFGGDPRRVTLAGHAAGAALVNALLMLPDSKGLVSRVLLLSGSALSPAA

\begin{tabular}{llllllll}
\hline 310 & 320 & 330 & 340 & 350 & 360 & 370 & 380
\end{tabular}
SVHDPNDLRLKVGEQIGCSTENDED---IADCLRGVPLRELMAVELPEIRFVPRIGPGLPVDQN---NPDPGLDMERASDTFIKVPLILGVSTTESNLGF LAPDATLTRDHTAQALRCIPENSNDENWFVECIRARPLAALLAVEAPKARFLSGWAPSVPA-------GQPPTRALHASDTFLDCSLAIVVSTTESYQFF LAPDAALAREHTAQALRCTPEATNDENWFVECIRARPLAALLAVEAPRARFLAGWAPSVPVSRDVGSQGQAPTRALHASETFLDCALAVVVATTESYQFF

\begin{tabular}{ccccccccc}
\hline hand metal binding & \multicolumn{3}{c}{ EF hand metal binding } \\
\hline 410 & 420 & 430 & 440 & 450 & 460 & 470 & 480 & 490
\end{tabular}
NENDIQYGFEEDHRNRILRTFIRNAYVYHLNEIFSAVRNEYTDWDKPILHPIIIRDSTMEALSDGHTVAPLMRIAFYHARRGAKTYFYHFSHQTKESGML NEDDIRHGFEEEHRNRILRTYVRNVYRYHRNEIFAAIRNEYTDWEKPIQHPINIRDATLDSLSDGAVAAPALRLAQLHARRGSTTYFAHFAHQTKDADYP NEEDIRHGFEEEHRNRILRTYVRNVYRYHRNEIFAAIRNEYTDWEKPIQHPINIRDATLESLSDAAVTAPALRVAQLHARRGARTYFAHFAHQSKDADYP

520

530

540

550

560

570

580

590

600 QRLGSIRGEDISYIFGLPLVGGGAFFSRNYSRQDQTVAEAVLTFFTNFAKTGNPNEPHKIESVDYGTPKEKTRYRGLTWEQYETGIQQYLTIAMKPKMKS QRLGSITSETLPYFLGLPLVSGTPSNLRNYSRGDVAVAESAVALLAAFAKTGDPTA----------RSEERHHDNSVTWPRYEINTQQYLS IGTKLRVKS QRLGSVTSETLPYFLGLPLVGGMQLAPRNYSRGDVAVAETAVSLLAAFAKTGDPTP----------RAEDRHHDGPTTWPRYEMNTQQYLSIGTKLRVKS

620

630

640

650

660

670

680

690

700

HYRGHKMAVWLNLIPQLHRPGDDDVSMRHHHFRERGDHFYAGPVRDEWYTPLPLVGTTKASASSTTACSTTTGDD---SITEDITPILDDSEDDAELLQR HYRGHKLALWLHLVPQLHRPG---AAPRHHQFRSVHPAMFAGEIFPELYTTTAALDDDEEISEAEEDSSEVEECEPSPSPRPALSALPSLQPTPKEDSLT HYRGHKMALWLHLIPQLHRPG---AAPRHHQFRS IHPDMFAGEIFPELYTTTSALDDEEDSTEPEEDSSEVEECEPSPSPRPALSALPAPQPSPKEDSLT

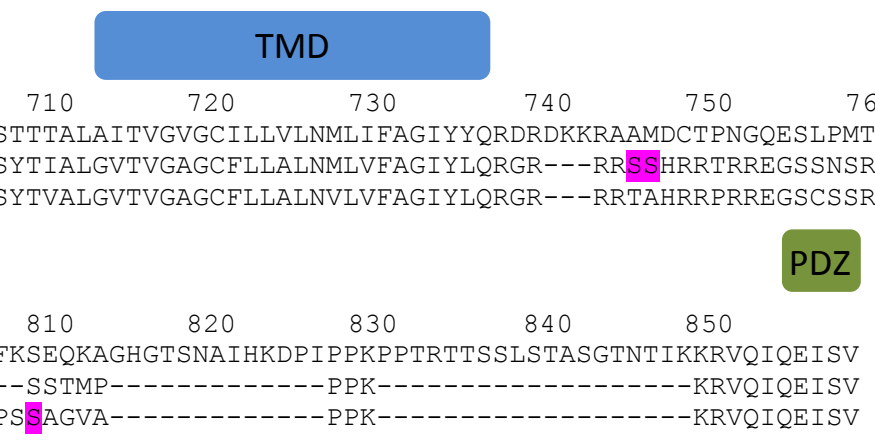




\section{Figure S3: Neurexin I Multiple Alignment}

\section{Signal peptide}

\section{0}

30

40

Laminin G-like domain (1)

$\begin{array}{llll}50 & 60 & 70 & 80\end{array}$

$80 \quad 90$

100 $\ldots|\ldots| \ldots|\ldots| \ldots|\ldots| \ldots|\ldots| \ldots|\ldots| \ldots|\ldots| \ldots|\ldots| \ldots|\ldots| \ldots|\ldots| \ldots|\ldots| \ldots|\ldots| \ldots|\ldots| \ldots \mid$ MHPSVGNVGTLLPLLVVLLSQVAMSFVLEGSATSYAQFRKWNAGLNGTLEFEFKTEQGNGLLLYTDDGGTYDFFEAKLVESALRLRYNLGGGAQIVTVGH MPSAVATMRYALLCLLSFSLSTTFAFVLD-KQNPYSQFRKWNAGLNGTIEIEFKTDQPNGLLLYTDDGGTYDFFELKLVNGGLRLRYNLGGGAQILTVGN MPSDVATMRYILFCLLSLSFNRNFAFVLD-KQNPYSQFRKWNAGLNGTLELEFKTDQPNGLLLYTDDGGTYDFFELKLVNGALRLRYNLGGGAQI ITVGS BmNrxI SINrXI

AmNrxI BmNrxI SINrXI

AmNrxI BmNrXI SINrXI

$\operatorname{AmNrxI}$ BmNrxI SINrXI

AmNrxI BmNrxI SINrXI

AmNrxI BmNrxI SINrXI

AmNrxI BmNrxI SINrXI

AmNrxI BmNrxI SINrXI

\begin{tabular}{llllllll}
\hline 110 & 120 & 130 & 140 & 150 & 160 & 170 & 180 \\
\hline.$\ldots$
\end{tabular}
$\ldots \ldots|\ldots| \ldots|\ldots| \ldots|\ldots| \ldots|\ldots| \ldots|\ldots| \ldots|\ldots| \ldots|\ldots| \ldots|\ldots| \ldots|\ldots| \ldots|\ldots| \ldots$ DIGDGHWHKVUTRCAENTTITVGVSAVSTSRGKEFEFGKI NLNDGHWHKVQVARRDEHTTLTVDGISQTKTSRGKEFAFGKFTTNSDVFVGGIPPSYDSKLATLALPSVIFEPKFRGAVRNLVYSDLPGQPPRRQELR-NLNDGHWHKVQVARRDEPTSLTVDGITQSKTSRGKEFAFGKFNSNSDVFVGGIPPSYNSKLTTLALPSVIFEPKFRGSVRNLVYSDLPGQPPRRQELR--

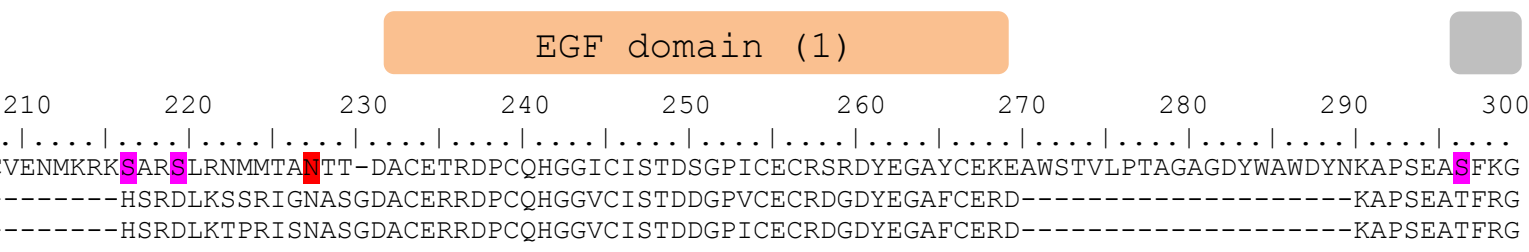

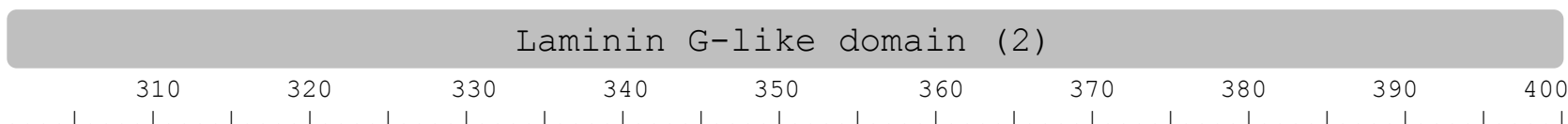
TEYLTIDLSK--GDPILSTQETVNLQFKTKQPNGLLFYSANGRNRASCPTGEGDDYLTISLRDGGVAVGMTLAKGRLDLHIKPVRVRFDDNQWHRI IVHR AEFLSYDLTQTGGEPIVSTQDTISLYFKTRQPNGLLFY-----------TGHEADYLNLAVRDGGVSLTMGLGNGKQEMHIKPSKTRFDDHQWHKLTVHR AEFLSYDLTQTGGEPIVSTQDAISLYFKTRQPNGLLFY----------TGHEADYLNLAVRDGGVSLTMGLGNGKQEMHIKPAKTRFDDHQWHKLTVHR

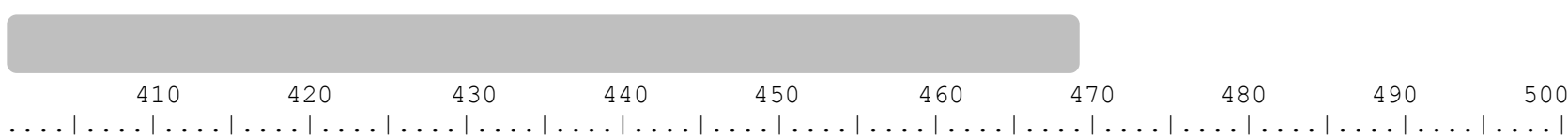
$\ldots|\ldots| \ldots|\ldots| \ldots|\ldots| \ldots|\ldots| \ldots|\ldots| \ldots|\ldots| \ldots \ldots|\ldots| \ldots|\ldots| \ldots|\ldots| \ldots|\ldots| \ldots|\ldots| \ldots|\ldots| \ldots|\ldots|$ KVQEISSITSFCRLSAIVDGIYAEHGHTAGSFTHLASDRLLVGGGADARSLQGAKGINNFNGCLRKVEFVAEGVRMELIEAARSGAAGAAAWGKMDFHCR RIQEVTSFTSFCRVSAIVDDVYSDHSHVAGSFTMLASSRAHVGGSLNARALPGARVHTNFIGCLKKVEFSADTLRLNLIDLARTGSKLITVTGRLEYSCI RIQEITPFTSFCRVSAVVDDVYSDHSHVAGSFTMLASSRAHVGGSLNARALPGARVHTNFIGCLKKVEFSADTLRLNLIDLARTGSKLITVTGRLEYACT

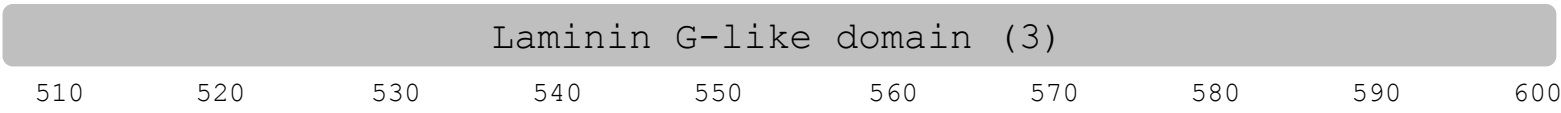
$\ldots|\ldots| \ldots|\ldots| \ldots|\ldots| \ldots|\ldots| \ldots|\ldots| \ldots|\ldots| \ldots|\ldots| \ldots|\ldots| \ldots|\ldots| \ldots|\ldots| \ldots|\ldots| \ldots|\ldots| \ldots \mid$ EPRSSDPITFTTRDPHLVLPPWRAAKSGSISFKIRTNEPNGLIMYSRSGAHTSKISSHSKSLEVIIS------TYRSRKRTCKVKSSKQRIDNGIWHDVA ATDSADPVTFTTRDAHLILPKWEAVKTGTISFKFRTNEPNGLILFN-MGAKPPR----ADLFAVEILNGYIYVHVDLGSGGVKVRASRRRVDDSLWHDFL ATDSADPVTFTTRDAHLI LPKWEAVKTGT ISFKFRTNEPNGLVLFN-MGAKP PRVGCTADLFAVEILNGY IYVHIDLGSGGVRVRASRRRVDDSHWHDFL

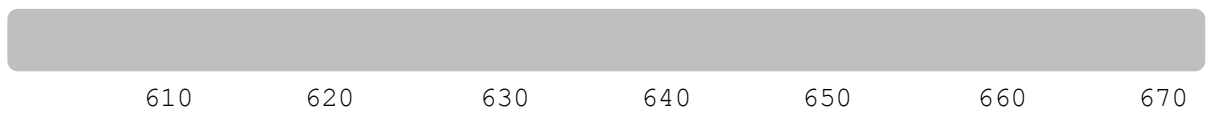

680

690

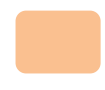
$\ldots|\ldots| \ldots|\ldots| \ldots|\ldots| \ldots|\ldots| \ldots|\ldots| \ldots|\ldots| \ldots|\ldots| \ldots|\ldots| \ldots|\ldots| \ldots|\ldots| \ldots|\ldots| \ldots|\ldots| \ldots \mid$ LRRVERDGRVTVDDS IVEFRTPGDSTQLDLDGLLHIGGVGAPFAPLTVP PVLWTGALRQGYVGCIRDLVINGQ IDIAGYAQQQD SGAVKPACHFQQSHC LRRSGRDGRVTVDGANAEFKTPGESNQLELDGPLYVGGLGSEYSASRTPPVLWTAALRQGFVGCVRDLTLNGKSQDLTAFARQQDSASVRPACHVLMKQC LRRSGRDGRVTVDGANAEFKTPGESNQLELDGPLFVGGLGSEYSASRTP PALWTAALRQGFVGC IRDLVLNGKPQDLTAYARQQDSASVRPACHVLMKQC

EGF domain $(2)$
710
720


AmNrxI BmNrxI SINrXI

AmNrxI BmNrxI SINrXI

AmNrxI BmNrxI SINrXI

\begin{tabular}{llllllll}
\hline 810 & 820 & 830 & 840 & 850 & 860 & 870 & 880
\end{tabular}

810

820

830

840

850

860

870

890

900

$\ldots|\ldots| \ldots|\ldots| \ldots|\ldots| \ldots|\ldots| \ldots|\ldots| \ldots|\ldots| \ldots|\ldots| \ldots|\ldots| \ldots|\ldots| \ldots|\ldots| \ldots|\ldots| \ldots|\ldots| \ldots|\ldots| \ldots \mid \ldots$ HIGDKEKTLVAGQGLNDDMWHTLRFSRRASSLKFQIDDEAAVRAETQLGKQS ILEFRTLHVGGYLHAGEEI------PHFVGQLQQIWFNGYPYLEIARS RLGDREKNLLAGTNVADDNWHTVRFSRRASNLRLQVDGAASVRAETILGKASTLEISTLHLGGLYHPEEEIQMTSTLPNFVGYIQKFVFNGIKYIDMAKA RLGDREKNLLAGTNVADDTWHTVRFSRRASNLKLQVDGAQPVRAETILGKASTLEISTLHLGGLFHPEEEIQMTSTLPNFVGYLQKFVFNGIRYIDMAKT

\section{Laminin G-like domain (5)}

910 920

930

940

960

970

980

990

1000 $\ldots|\ldots| \ldots|\ldots| \ldots|\ldots| \ldots|\ldots| \ldots|\ldots| \ldots|\ldots| \ldots|\ldots| \ldots|\ldots| \ldots|\ldots| \ldots|\ldots| \ldots|\ldots| \ldots|\ldots| \ldots|\ldots| \ldots|\ldots| \ldots$ SGNHQASHQG---VTPI IRVTGKFGKRNHP-VHHPVTFTSKHTFVGLPVLKAYVETNIYFQFKTREANGLILYNAGRERDFIAVELVNGHIHYVFDLGDG LGVGSGEEHNRIYDTSNI IFNGRFVKPDSLNVYKAVTFKSKHTYVGLPLLKAYANTYLDFYFRTTEMDGLLFYNGGKKQDFIAIELVSGHVHCVFNLGDG LGVGTNEETNNIYDTSNLIFTGKFVKPDSLNVYKSVTFKSKHTYVGLPLLKAYANTYLDFYFRTTEMDGLLFYNGGKKQDFIAVELVNGHIHCVFNLGDG

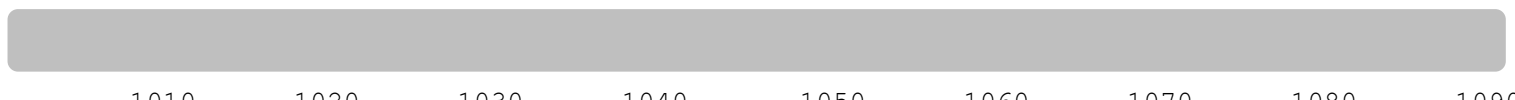

1010

1020

1030

1040

1050

1060

1070

1080

1090

1100 $\ldots|\ldots| \ldots|\ldots| \ldots|\ldots| \ldots|\ldots| \ldots|\ldots| \ldots|\ldots| \ldots|\ldots| \ldots|\ldots| \ldots|\ldots| \ldots|\ldots| \ldots|\ldots| \ldots|\ldots| \ldots|\ldots| \ldots \ldots$ PVRIRDTSRSKLNDGKWHAVSIGRPAPKRHTLAVDDHVTAVN---SQGSTRSDLDEFCFIGGVEKSQYGQLPKQILSKHGFEGCLASLDLSGESTNLISD VVTMKDKLKNFLNDNRWHTVSVRRPTPKIHTLQVDDDIEILYYLFSGSNLMLELDSVLYVGGVPKDMYTVLPVGVLSRQGFEGCMSSLDLPGESPSLLED VVTMKDKLKNFLNDNRWHTVSVRRPTPKI HTLQVDDDLEMHT---TSSNLMLELDSVLYVGGVPKDMYTALPVGVLSRQGFEGCMSSLDLPGESPSLMED

$\operatorname{AmNrxI}$ BmNrxI SINrXI

AmNrxI BmNrxI SINrXI

\section{EGF domain (3)}

1110

1120

1130

1140

1150
Laminin G-like domain (6)

1160

1180

1190

1200 $\ldots|\ldots| \ldots|\ldots| \ldots|\ldots| \ldots|\ldots| \ldots|\ldots| \ldots|\ldots| \ldots|\ldots| \ldots|\ldots| \ldots|\ldots| \ldots|\ldots| \ldots|\ldots| \ldots|\ldots| \ldots|\ldots|$ AVVPSSLVESGCDMYANLHPGKKCTHDVCSNHGTCVQQWNSYTCDCDTTSFTGPTCNEEAAAYEFGPGKGIITYTFPPNQRPEMKKDTVALGFVTSVNDA AVVPSSSLGSGCEGPT------KCTHNACANKGVCVOQWNTYVCDCDLTSFTGPTCYDESIAYEFGPSRGTITYTFPPSSVADTEMDKVALGFVTSKADA AVVPSSSLGSGCEGPT------KCTHNACANKGVCVQQWNTYVCDCDLTSFTGPTCYDESVAYEFGPGRGIITYTFPTDSVADTETDKVALGFVTSKADA

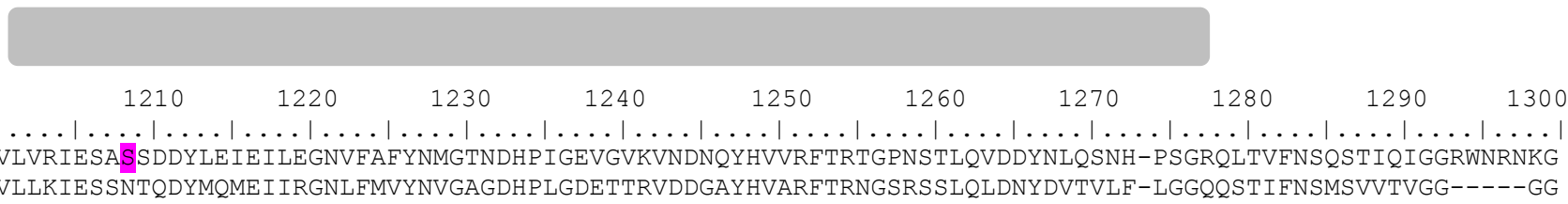
VLLRIESSNTQDYMQMEI IRGNLFMVYNVGGGDHPLGDETARVDDGAYHVARFTRNGSRASLQLDNYAVIIRHPQGGQQSTIFNGMSTIAVGG-----GA

AmNrxI BmNrxI SINrXI
1310

1320

1330

1340

1350

1360

1370

1380

1390

1400 $\ldots|\ldots| \ldots|\ldots| \ldots|\ldots| \ldots|\ldots| \ldots|\ldots| \ldots|\ldots| \ldots|\ldots| \ldots|\ldots| \ldots|\ldots| \ldots|\ldots| \ldots|\ldots| \ldots|\ldots| \ldots|\ldots|$ RVERPFLVLIAGLVVNGARILELAVSKDGRVVTRGDVQLLPPGSLLDRAAPLQRMQQTPAPGF--PGVMDDS IFSGAGSGCAADDEDEECTPIYEP-DDI GSARPYSGVLAGLVVDGVRVLELAAAGDPAVSVRGDVRRAHAP--LDR--DINRMQOTPPSGYGGPGVLDELVYSGAGSGCRDDDEDACVLPDAGSGDDL GGARSFSGVIAGAVVDGVRLLDLAAAGDPAVSVRGDARRAHTP--LDR--DINRMQQTPPSGYGGPGVLDELVYSGAGSGCRDDDEDACVLPDAGSGDDL
$\operatorname{AmNrxI}$

BmNrxI SINrXI
1410

1420

1430

1440

1460

1470 ITPVYVPSTRRPPSKTHKGDTSGKLMKP-CDDE-DCIEGSGSNGEEITEPERPATTSMSSSTHSMT-PPAPAT-TERLRP--------DVTSPDVTSHEV ITPVYVPSTRRPPSRLHKGDTSGKLMKP-CDDE-DCIEGSGSSVDEITEPDHPMTTSGASSTHSMTSPTAPVLSTARDEKPLEGSTAGDTHTATSSSAGL
AmNrxI

BmNrxI

SINrXI
1510 1520

1530

1540

1550

1560

1570

1580

1590

1600 $\ldots|\ldots| \ldots|\ldots| \ldots|\ldots| \ldots|\ldots| \ldots|\ldots| \ldots|\ldots| \ldots|\ldots| \ldots|\ldots| \ldots|\ldots| \ldots|\ldots| \ldots|\ldots| \ldots|\ldots| \ldots|\ldots|$ 作 PRTTLPDHDNIHAATFGVHTETNRKTTP-DDHTHT---AHFTP--TDRHE-EEPTHTTAEDTNHMPEYEDRNENEIEARTPTYEIEGEQDRAPGRVHPDY P-PTAPDHDNMHAGTLDTATPPERRTTPTDEHSHTHTSYHFTPTLTGKHIPDEPTHTTEEDTNHIPEYEDRRENEIEARTPTYETESEQDRIPGRVHPEY 


\section{TMD}

1620

1630

1640

1650

1660

1670

1680

1690

1700

$\ldots|\ldots| \ldots|\ldots| \ldots|\ldots| \ldots|\ldots| \ldots|\ldots| \ldots|\ldots| \ldots|\ldots| \ldots|\ldots| \ldots|\ldots| \ldots|\ldots| \ldots|\ldots| \ldots|\ldots| \ldots|\ldots|$

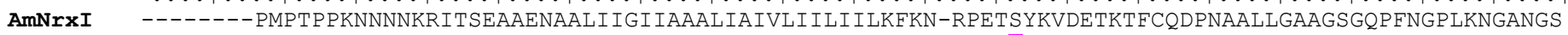

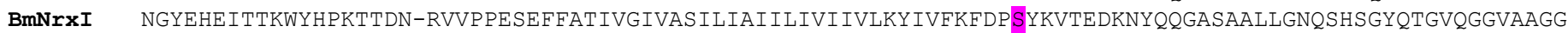

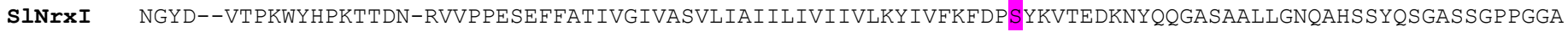

\section{PDZ}

$1710 \quad 1720 \quad 1730$

$\ldots|\ldots| \ldots|\ldots| \ldots|\ldots| \ldots|\ldots| \ldots$

$\begin{array}{ll}\text { AmNrxI } & \text { KT- } \\ \text { BmNrxI } & \text { QG------ GAGRPLQPLAAPPPHPVKRDGIKEWYV }\end{array}$

SINrxI VRNLQPLPLNRNGAAPTAPLAPIPTQPVKRDGIKEWYV 